Subscriber access provided by Brought to you by ST ANDREWS UNIVERSITY LIBRARY

\title{
Article
}

\section{One-Pot Three-Component Condensation Synthesis and Structural Features of Organophosphorus-Sulfur Macrocycles}

Guoxiong Hua, Junyi Du, David B. Cordes, Alexandra M. Z. Slawin, and John Derek Woollins

J. Org. Chem., Just Accepted Manuscript • DOI: 10.1021/acs.joc.6b00573 • Publication Date (Web): 02 May 2016

Downloaded from http://pubs.acs.org on May 9, 2016

\section{Just Accepted}

"Just Accepted" manuscripts have been peer-reviewed and accepted for publication. They are posted online prior to technical editing, formatting for publication and author proofing. The American Chemical Society provides "Just Accepted" as a free service to the research community to expedite the dissemination of scientific material as soon as possible after acceptance. "Just Accepted" manuscripts appear in full in PDF format accompanied by an HTML abstract. "Just Accepted" manuscripts have been fully peer reviewed, but should not be considered the official version of record. They are accessible to all readers and citable by the Digital Object Identifier (DOI®). "Just Accepted" is an optional service offered to authors. Therefore, the "Just Accepted" Web site may not include all articles that will be published in the journal. After a manuscript is technically edited and formatted, it will be removed from the "Just Accepted" Web site and published as an ASAP article. Note that technical editing may introduce minor changes to the manuscript text and/or graphics which could affect content, and all legal disclaimers and ethical guidelines that apply to the journal pertain. ACS cannot be held responsible for errors or consequences arising from the use of information contained in these "Just Accepted" manuscripts. 


\title{
(S) Supporting Information
}

\section{Organophosphorus-Sulfur Macrocycles}

\author{
Guoxiong Hua, Junyi Du, David B. Cordes, Alexandra M. Z. Slawin and J. Derek Woollins* \\ EaStCHEM School of Chemistry, University of St Andrews, Fife, KY16 9ST, UK
}

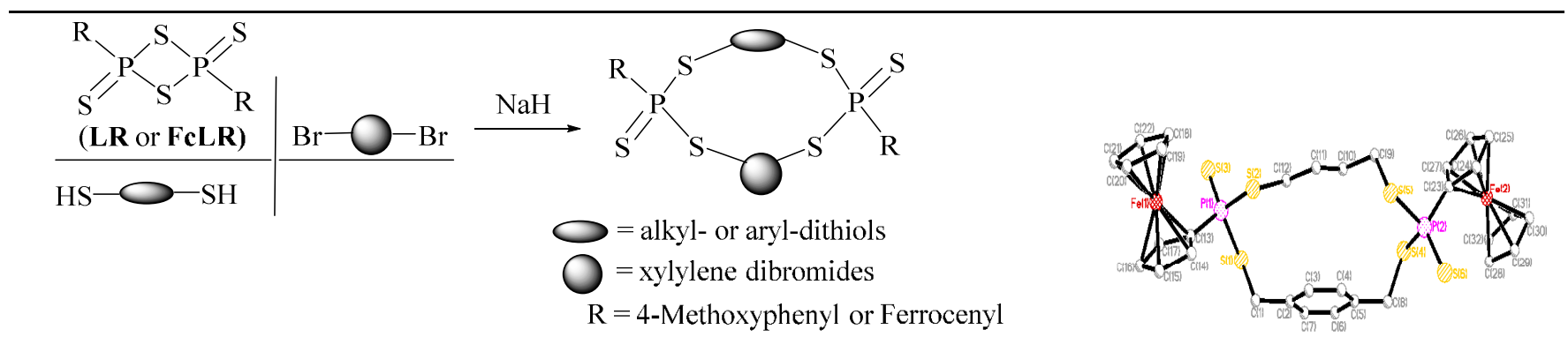

\begin{abstract}
A new preparative route was developed to synthesize new phosphorus-sulfur [-SP(=S)S- moiety] containing macrocycles via a one-pot and three-component domino reaction of four-membered ring thionation reagents such as 2,4-bis(4-methoxyphenyl)-1,3,2,4-dithiadiphosphetane 2,4-disulfide (LR, Lawesson's Reagent) and 2,4-diferrocenyl-1,3,2,4-diathiadiphosphetane 2,4-disulfide (FcLR, a ferrocene analogue of Lawesson's Reagent) and alkyldithiols(aryldithols) and dihaloalkanes in the presence of sodium hydride. Therefore, a series of twelve- to eighteen-membered macrocycles incorporating two phosphorus and six sulfur atoms were synthesized. The synthesis features a novel application of the multicomponent reaction, providing an efficient route to the preparation of the new phosphorus sulfur containing macrocycles. Seven representative X-ray structures confirm the formation of these macrocycles and show the presence of a number of the intramolecular $\mathrm{C}-\mathrm{H} \cdots \mathrm{S}$ hydrogen bonding, intermolecular $\mathrm{C}-\mathrm{H} \cdots \mathrm{S}, \mathrm{C}-\mathrm{H} \cdots \mathrm{Cl}$ and $\mathrm{Cl} \cdots \mathrm{Cl}$ short contacts and $\pi$-stacking interactions in their 3D network structures.
\end{abstract}




\section{INTRODUCTION}

Organic macrocycles containing multi-sulfur linkages are of importance for the study of functions and structures of proteins in chemical biology. They can, in many cases, be used as pro-drug molecules due to the organic sulfides displaying a remarkable range of properties in comparison to their oxygencontaining analogues; they can be more nucleophilic, less basic, and less polar, and easily oxidized to form sulfoxides and sulfones that provide additional opportunities for structural diversification. ${ }^{1-10}$ Phosphorus-containing macrocyclic compounds are also interesting molecules with potential application in supramolecular, coordination and synthetic organic chemistry. ${ }^{11-14}$ Many synthetic methods have been developed such as the preparation of cyclic polysulfides by using either elemental sulfur or other sulfurtransfer reagents. In addition, systematic and selective synthesis of benzene-fused cyclic polysulfides by introduction of bulky substituents on the benzene ring has also been explored. ${ }^{15-17}$ However, these methods often give poor yields of the desired products. ${ }^{18-23}$ Herein, we report a 'one-pot' threecomponent condensation via a small ring expansion of Lawesson's Reagent, a well known thionation reagent in organic and organometallic syntheses ${ }^{24,25}$ or its ferrocene analogue, 2,4-diferrocenyl-1,3,2,4diathiadiphosphetane 2,4-disulfide (FcLR) by consecutively introducing two organic building blocks to construct a series of phosphorus-sulfur macrocyclic scaffolds incorporating two phosphorus atoms and six sulfur atoms linkages. We aimed at producing a library of phosphorus-sulfur macrocycles in one simple step starting from three simple difunctional building blocks, namely, thionation reagents, dithiols, and dihaloalkanes in the presence of a strong base. To the best of our knowledge, this is the first report of the synthesis and X-ray structure of such organo phosphorus-sulfur macrocycles containing the $\operatorname{SP}(\mu$ $\mathrm{S}) \mathrm{SC}_{\mathrm{n}} \mathrm{SP}(\mu-\mathrm{S}) \mathrm{S}$ linkage. 


\section{RESULTS AND DISCUSSION}

\section{Synthesis and Characterization}

The two reagents utilized to accomplish a series of one-pot three-component reactions are: Lawesson's Reagent (LR), which is commercially available, and a ferrocene analogue of Lawesson's Reagent, 2,4diferrocenyl-1,3,2,4-diathiadiphosphetane 2,4-disulfide $[\mathrm{FcP}(\mu-\mathrm{S}) \mathrm{S}]_{2}$ (FcLR), for which the preparation, spectroscopic characterisation and crystal structure have been reported by our group. ${ }^{26,27}$ The one-pot three-component reactions of 2,4-bis(4-methoxyphenyl)-1,3,2,4-dithiadiphosphetane 2,4-disulfide (LR) with an equimolar amount of dithiol and dibromide in the presence of two equimolar amounts of sodium hydride at room temperature for $24 \mathrm{~h}$ led to the corresponding twelve- to sixteen-membered phosphorussulfur macrocycles 1-10 in 45 to 67\% yields, respectively, as depicted in Scheme 1 and Table 1 . In all the cases, insoluble (in water or normal organic solvents such as dichlomomethane, tetrahydrofuran, chloroform, hexane, ethyl ether, acetone etc.) side products which we were not able to identify, but which we assume are linear polymers, were found resulting in the average yields. The reactions tolerate diverse dithiol substrates such as alkyl-dithiol and aryl-dithiols. Among dibromides, the $o$-xylylene dibromide was found to be preferable for high yields in the current macrocyclization in general, compared to the $m$-xylylene dibromide and $p$-xylylene dibromide, for instance, the combination of the propane-1,2-dithiol and $o$-xylylene dibromide gave 10 with the highest yield (67\%). It is worth noting that in all cases diastereomeric product was obtained based on the ${ }^{31} \mathrm{P}$ NMR spectral analyses. The designed, three-component reactions provided a rapid, atom-efficient, and step economic method to construct phosphorus-sulfur macrocycles. 


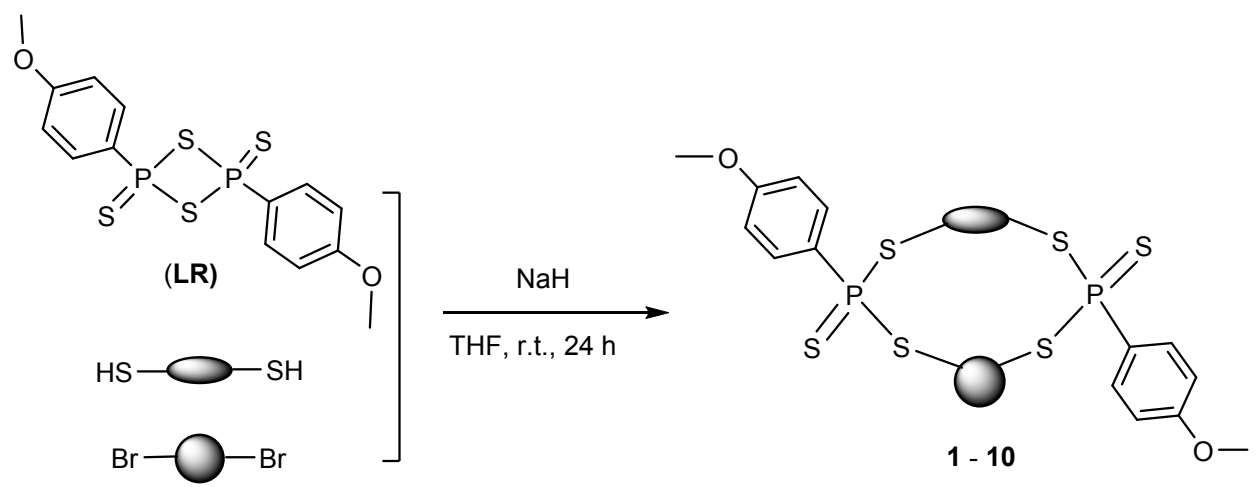

Scheme 1. Synthesis of phosphorus-sulfur macrocycles 1-10 ( $\bigcirc, \bigcirc$ and $\mathrm{R}$ groups defined in Table 1)

Table 1. Group definition, yields and ${ }^{31} \mathrm{P}$ NMR data of compounds 1-10

\begin{tabular}{|c|c|c|c|c|}
\hline Compound & 8 & 0 & Yield (\%) & ${ }^{31} \mathrm{P}$ NMR $(\delta, \mathrm{ppm})$ \\
\hline 1 & $\left(\mathrm{CH}_{2}\right)_{2}$ & $1,2-\mathrm{CH}_{2} \mathrm{C}_{6} \mathrm{H}_{4} \mathrm{CH}_{2}$ & 45 & $78.9 / 77.8$ \\
\hline 2 & $\left(\mathrm{CH}_{2}\right)_{2}$ & $1,3-\mathrm{CH}_{2} \mathrm{C}_{6} \mathrm{H}_{4} \mathrm{CH}_{2}$ & 65 & $81.3 / 80.9$ \\
\hline 3 & $\left(\mathrm{CH}_{2}\right)_{3}$ & $1,2-\mathrm{CH}_{2} \mathrm{C}_{6} \mathrm{H}_{4} \mathrm{CH}_{2}$ & 59 & $79.5 / 79.1$ \\
\hline 4 & $\left(\mathrm{CH}_{2}\right)_{3}$ & $1,3-\mathrm{CH}_{2} \mathrm{C}_{6} \mathrm{H}_{4} \mathrm{CH}_{2}$ & 55 & $83.1 / 83.0$ \\
\hline 5 & $\left(\mathrm{CH}_{2}\right)_{3}$ & $1,4-\mathrm{CH}_{2} \mathrm{C}_{6} \mathrm{H}_{4} \mathrm{CH}_{2}$ & 58 & $81.5 / 81.2$ \\
\hline 6 & $\left(\mathrm{CH}_{2}\right)_{4}$ & $1,2-\mathrm{CH}_{2} \mathrm{C}_{6} \mathrm{H}_{4} \mathrm{CH}_{2}$ & 45 & $80.4 / 80.2$ \\
\hline 7 & $\left(\mathrm{CH}_{2}\right)_{4}$ & $1,3-\mathrm{CH}_{2} \mathrm{C}_{6} \mathrm{H}_{4} \mathrm{CH}_{2}$ & 56 & $82.1 / 82.0$ \\
\hline 8 & $\left(\mathrm{CH}_{2}\right)_{4}$ & $1,4-\mathrm{CH}_{2} \mathrm{C}_{6} \mathrm{H}_{4} \mathrm{CH}_{2}$ & 49 & $82.7 / 82.6$ \\
\hline 9 & 4H-pyrazole-3,5-diyl & $1,4-\mathrm{CH}_{2} \mathrm{C}_{6} \mathrm{H}_{4} \mathrm{CH}_{2}$ & 46 & $83.3 / 82.8$ \\
\hline 10 & $1,2-\mathrm{CH}_{2} \mathrm{C}_{6} \mathrm{H}_{4} \mathrm{CH}_{2}$ & $1,2-\mathrm{CH}_{2} \mathrm{C}_{6} \mathrm{H}_{4} \mathrm{CH}_{2}$ & 67 & $77.3 / 77.1$ \\
\hline
\end{tabular}


Similarly, the three-component reaction of 2,4-diferrocenyl-1,3,2,4-diathiadiphosphetane 2,4-disulfide $[\mathrm{FcP}(\mu-\mathrm{S}) \mathrm{S}]_{2}$ (FcLR) with an equimolar amount of dithiol and dibromide in the presence of two equimolar amounts of sodium hydride at room temperature for $24 \mathrm{~h}$ gave rise to the corresponding twelve- to eighteen-membered phosphorus-sulfur macrocycles $\mathbf{1 2 - 2 5}$ in 40 to $80 \%$ yields as shown in Scheme 2 and Table 2. Surprisingly, a seven-membered heterocycle $\mathbf{1 1}$ also formed simultaneously and is isolated in $18 \%$ to $24 \%$ yields when the $o$-xylylene dibromide was involved as a building block in the reaction. Once again, in all the cases, insoluble (in water or normal organic solvent) by-products which we were not able to identify were found. The one-pot three-component reactions are satisfactory with dithiol substrates from alkyl-dithiol to aryl-dithios. The results showed that the $o$-xylylene dibromide was preferable to achieve high yields for both macrocycles and heterocycle $\mathbf{1 1}$ in the three-component condensation reactions, compared to the $m$-xylylene dibromide and $p$-xylylene dibromide. It is worth noting that in all cases diastereomeric products were obtained.
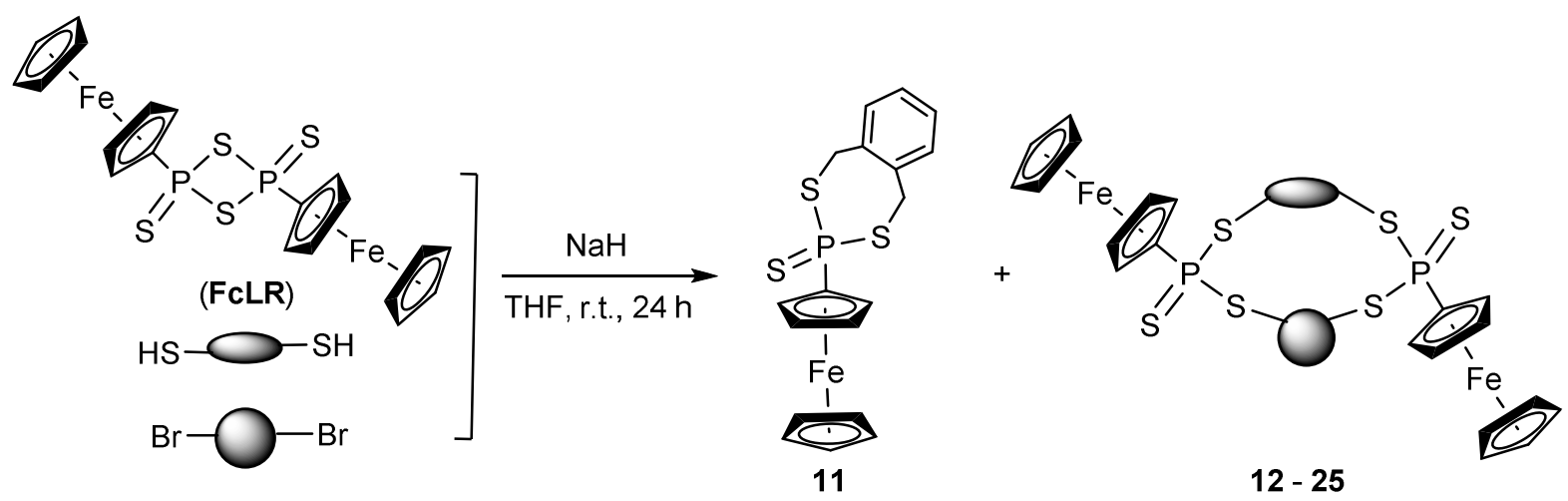

Scheme 2. Synthesis of heterocycle 11 and macrocycles 12-25 ( $\bigcirc, O$ and R groups defined in Table 2) 
Table 2. Group definition, yields and ${ }^{31} \mathrm{P}$ NMR data of compounds 12-25

\begin{tabular}{|c|c|c|c|c|}
\hline Compound & 0 & O & Yield (\%) & ${ }^{31} \mathrm{P}$ NMR $(\delta, \mathrm{ppm})$ \\
\hline 12 & $\left(\mathrm{CH}_{2}\right)_{2}$ & $1,4-\mathrm{CH}_{2} \mathrm{C}_{6} \mathrm{H}_{4} \mathrm{CH}_{2}$ & 64 & $81.9 / 81.8$ \\
\hline 13 & $\left(\mathrm{CH}_{2}\right)_{3}$ & $1,2-\mathrm{CH}_{2} \mathrm{C}_{6} \mathrm{H}_{4} \mathrm{CH}_{2}$ & 73 & $79.8 / 79.7$ \\
\hline 14 & $\left(\mathrm{CH}_{2}\right)_{3}$ & $1,3-\mathrm{CH}_{2} \mathrm{C}_{6} \mathrm{H}_{4} \mathrm{CH}_{2}$ & 45 & $82.7 / 80.3$ \\
\hline 15 & $\left(\mathrm{CH}_{2}\right)_{3}$ & $1,4-\mathrm{CH}_{2} \mathrm{C}_{6} \mathrm{H}_{4} \mathrm{CH}_{2}$ & 45 & $80.2 / 79.7$ \\
\hline 16 & $\left(\mathrm{CH}_{2}\right)_{4}$ & $1,2-\mathrm{CH}_{2} \mathrm{C}_{6} \mathrm{H}_{4} \mathrm{CH}_{2}$ & 71 & $79.7 / 79.6$ \\
\hline 17 & $\left(\mathrm{CH}_{2}\right)_{4}$ & $1,3-\mathrm{CH}_{2} \mathrm{C}_{6} \mathrm{H}_{4} \mathrm{CH}_{2}$ & 60 & $81.3 / 81.2$ \\
\hline 18 & $\left(\mathrm{CH}_{2}\right)_{4}$ & $1,4-\mathrm{CH}_{2} \mathrm{C}_{6} \mathrm{H}_{4} \mathrm{CH}_{2}$ & 60 & $81.8 / 81.6$ \\
\hline 19 & 4H-pyrazole-3,5-diyl & $1,2-\mathrm{CH}_{2} \mathrm{C}_{6} \mathrm{H}_{4} \mathrm{CH}_{2}$ & 80 & $95.1 / 95.0$ \\
\hline 20 & 4H-pyrazole-3,5-diyl & $1,3-\mathrm{CH}_{2} \mathrm{C}_{6} \mathrm{H}_{4} \mathrm{CH}_{2}$ & 60 & $83.7 / 82.7$ \\
\hline 21 & 4H-pyrazole-3,5-diyl & $1,4-\mathrm{CH}_{2} \mathrm{C}_{6} \mathrm{H}_{4} \mathrm{CH}_{2}$ & 59 & $80.0 / 79.6$ \\
\hline 22 & $1,2-\mathrm{CH}_{2} \mathrm{C}_{6} \mathrm{H}_{4} \mathrm{CH}_{2}$ & $1,2-\mathrm{CH}_{2} \mathrm{C}_{6} \mathrm{H}_{4} \mathrm{CH}_{2}$ & 55 & $78.2 / 78.0$ \\
\hline 23 & $1,2-\mathrm{CH}_{2} \mathrm{C}_{6} \mathrm{H}_{4} \mathrm{CH}_{2}$ & $1,3-\mathrm{CH}_{2} \mathrm{C}_{6} \mathrm{H}_{4} \mathrm{CH}_{2}$ & 64 & $81.6 / 80.2$ \\
\hline 24 & $1,2-\mathrm{CH}_{2} \mathrm{C}_{6} \mathrm{H}_{4} \mathrm{CH}_{2}$ & $1,4-\mathrm{CH}_{2} \mathrm{C}_{6} \mathrm{H}_{4} \mathrm{CH}_{2}$ & 56 & $81.9 / 81.7$ \\
\hline 25 & $\left(\mathrm{CH}_{2}\right)_{4}$ & $\left(\mathrm{CH}_{2}\right)_{8}$ & 46 & 81.6(wide) \\
\hline
\end{tabular}

It is well known that $\mathbf{L R}$ (or FcLR) is believed to be in equilibrium with the monomeric form, which is the true reactive species in solution and can be presented as either of the forms $\mathbf{I a}$ and $\mathbf{1 b}$ as shown in 
Scheme 3. ${ }^{28,29}$ Two possible routes (A and B) are assumed to proceed via ring opening and closing reactions for the formation of macrocycles $\mathbf{1 - 1 0}$ and 12-25. In the route A, the reaction of Ia or Ib proceeds with one molecule of $\mathrm{HSCH}_{2} \mathrm{CH}_{2} \mathrm{SH} / \mathrm{NaH}$ via a nucleophilic opening reaction leading to the a disodium dithioate intermediate II and is followed by an alkylation of xylylene dibromide affording the macrocycles by loss of two molecules of $\mathrm{NaBr}$. In route B, Ia or Ib reacts with one molecule of xylylene dibromide resulting in a $\mathrm{P}-\mathrm{Br}$ intermediate $\mathbf{I I I},{ }^{30,31}$ the latter cyclises with $\mathrm{HSCH}_{2} \mathrm{CH}_{2} \mathrm{SH} / \mathrm{NaH}$ leading to the macrocycles by loss of two molecules of $\mathrm{NaBr}$ and one molecule of $\mathrm{H}_{2}$.

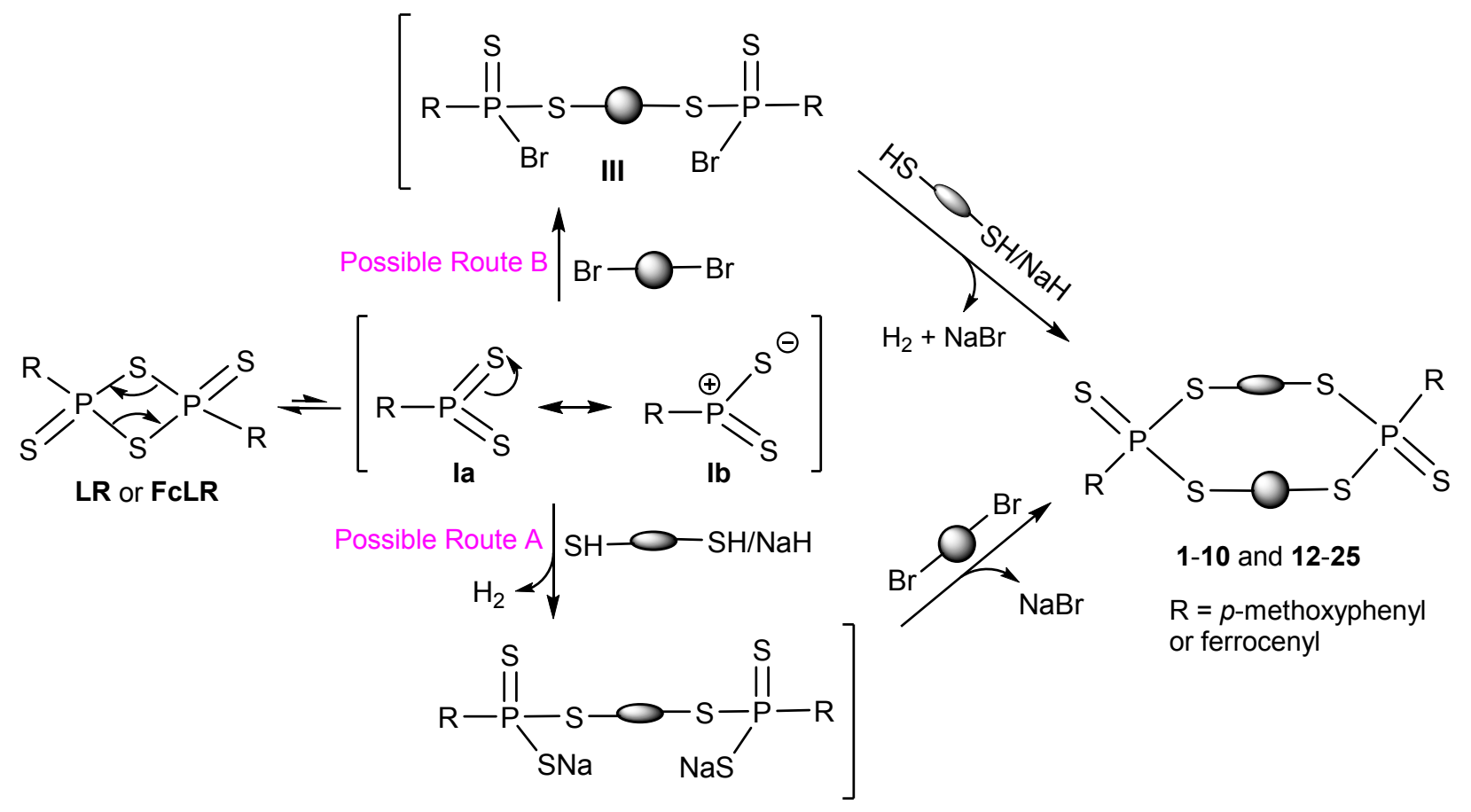

Scheme 3. Possible mechanism for the formation of macrocycles 1-10 and 12-25

In order to support and test the proposed mechanisms, the route A or B we chose the preparation of compound 12 as an example. Firstly, we carried on the reaction by following the route A: reacting FcLR with one equivalent of $\mathrm{HSCH}_{2} \mathrm{CH}_{2} \mathrm{SH} / \mathrm{NaH}$ [1:2 molar ratio] at room temperature for $2 \mathrm{~h}$ gave the intermediate sodium ethane-1,2-diyl bis(ferrocenylphosphonotrithioate), in which the ${ }^{31} \mathrm{P}$ NMR spectrum of the reaction mixture shows one single strong peak $\delta_{P} 70.1 \mathrm{ppm}$, the latter was treated in situ 
with one equivalent of 1,4-xylylene dibromide at room temperature for $22 \mathrm{~h}$ to give the expected macrocycle $\mathbf{1 2}$ after purification by silica gel column. For route B the reaction of FcLR with one equivalent of 1,4-xylylene dibromide at room temperature for $10 \mathrm{~h}$ led to the assumed $\mathrm{P}$-Br intermediate, in which the ${ }^{31} \mathrm{P}$ NMR spectrum of the reaction mixture displays two strong peaks $\delta_{P} 81.8$ and $96.1 \mathrm{ppm}$ with equal intensity, indicating the formation of mono- and di-P-Br intermediate. The $\mathrm{P}-\mathrm{Br}$ intermediate reacted in situ with $\mathrm{HSCH}_{2} \mathrm{CH}_{2} \mathrm{SH} / \mathrm{NaH}$ [1:2 molar ratio] at room temperature for $14 \mathrm{~h}$ resulting in a dark suspension, the ${ }^{31} \mathrm{P}$ NMR spectrum of the suspension exhibits one single strong peak $\delta_{P} 69.1 \mathrm{ppm}$, accompanied by several small peaks, only small amount of the product $\left(26 \mathrm{mg}, \delta_{P} 59.8 \mathrm{ppm}\right)$ was obtained after purification by silica gel column (eluted with 1:4 ethyl acetate/DCM), which was apparently not macrocycle $12\left(\delta_{P} 81.8\right.$ and $\left.81.9 \mathrm{ppm}\right)$, indicating the formation of another unknown product. Thus, the above results suggest that the formation of 1-10 and 12-25 proceeds through the route A. In addition, 11 might be the decomposed fragment of the macrocycles 13, 16, 19 and 22 (Scheme 4).

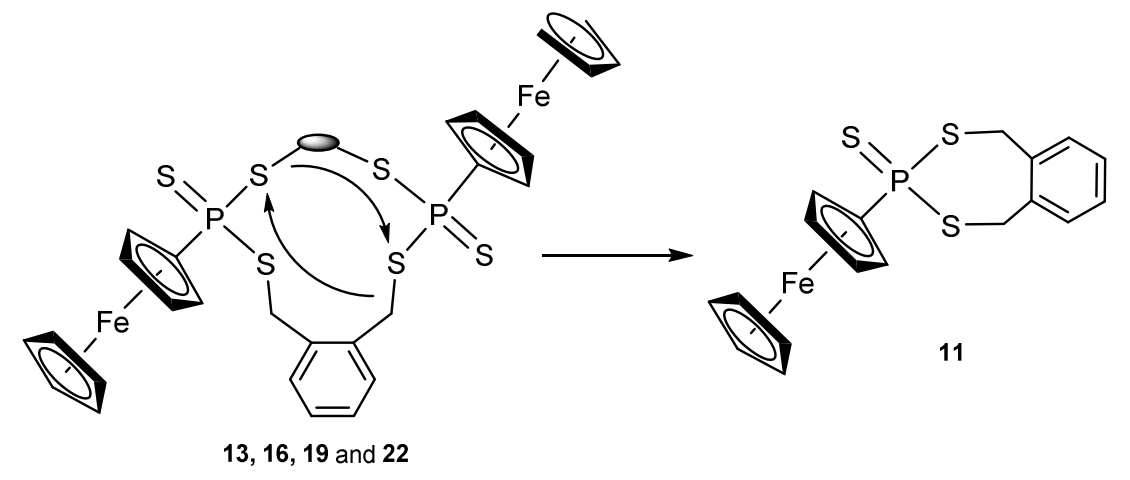

Scheme 4. Possible mechanism for the formation of macrocycle 11

The organo phosphorus-sulfur macrocycles 1-25 are soluble in common polar organic solvents and are air- and moisture-stable at ambient temperature for several months without any sign of the decomposition. All of the new compounds were characterized by standard analytical and spectroscopic techniques. Two phosphorus atoms in compounds $\mathbf{1 - 1 0}$ and $\mathbf{1 2 - 2 5}$ are potentially stereogenic centers, 
therefore, being stereotypic with $(R, R),(S, S),(S, R)$ and $(R, S)$ stereoisomers are possible. As anticipated two diastereomers are observed in compounds 1-10 and 12-24 in their ${ }^{31} \mathrm{P}$ NMR spectra though it is not possible to assign them specifically as shown in Tables 1 and 2; however, in $\mathbf{2 5}$ there is only one broad signal which might be two signals too close together to identify in its ${ }^{31} \mathrm{P}$ NMR spectrum, the ${ }^{1} \mathrm{H}$ NMR spectrum that reveals disproportionate numerical data for the peak areas (see Supporting Information) confirms two diastereomers are present. Compounds 1-25 show the anticipated $[\mathrm{M}]^{+}$or $[\mathrm{M}+\mathrm{H}]^{+}$peak in their mass spectra and satisfactory accurate mass measurements and appropriate isotopic distributions. The ${ }^{1} \mathrm{H}$ NMR and ${ }^{13} \mathrm{C}$ NMR spectra of compounds 11-25 display all the characteristic peaks of the ferrocene backbones. The ${ }^{31} \mathrm{P}$ NMR spectra of 1-10, and 12-25 exhibit sharp singlets in the range of $\delta$ 77.1 to $95.1 \mathrm{ppm}$. However, the chemical shifts of compounds $\mathbf{1 - 1 0}$, and $\mathbf{1 2 - 2 5}$ are clearly different, indicating substantial differences in macrocyclic conformation due to differences in ring current effects. Meanwhile, the ${ }^{31} \mathrm{P}$ NMR spectrum of compound $\mathbf{1 1}$ also shows a sharp singlet with a lower chemical shift of $\delta 50.2 \mathrm{ppm}$, compared to compounds 1-10, and 12-25.

\section{Single Crystal Structure Analysis}

Crystal of phosphorus-sulfur macrocycles 5, 10, 15, 18, 19, 22 and 24 suitable for X-ray crystallographic analysis were grown by diffusion of hexane into a dichloromethane solution of the compound. The structures have a single molecule of the compound in the asymmetric unit, except 10, which consists of two independent molecules, and compounds 19 and 24, in which both compounds have a single molecule of the compound and a molecule of dichloromethane. Detailed crystal data and structure refinement for compounds 5, 10, 15, 18, 19, 22 and 24 are collected in Tables 3 and 4. Selected bond lengths and angles are listed in Tables 5 and 6. 
Table 3. Details of the X-ray data collections and refinements for $\mathbf{5 , 1 0 , 1 5}$ and 18

\begin{tabular}{|c|c|c|c|c|}
\hline Compound & 5 & 10 & 15 & 18 \\
\hline Formula & $\mathrm{C}_{25} \mathrm{H}_{28} \mathrm{O}_{3} \mathrm{P}_{2} \mathrm{~S}_{6}$ & $\mathrm{C}_{30} \mathrm{H}_{30} \mathrm{O}_{2} \mathrm{P}_{2} \mathrm{~S}_{6}$ & $\mathrm{C}_{31} \mathrm{H}_{32} \mathrm{Fe}_{2} \mathrm{P}_{2} \mathrm{~S}_{6}$ & $\mathrm{C}_{32} \mathrm{H}_{34} \mathrm{Fe}_{2} \mathrm{P}_{2} \mathrm{~S}_{6}$ \\
\hline$M$ & 614.80 & 676.87 & 770.60 & 784.62 \\
\hline Crystal system & Orthorhombic & Triclinic & Triclinic & Monoclinic \\
\hline Space group & $\mathrm{Cmc}_{2}$ & $P-1$ & $P-1$ & $I 2 / a$ \\
\hline$a / \AA$ & $34.2(2)$ & $8.3619(13)$ & $7.47(4)$ & $23.798(3)$ \\
\hline$b / \AA$ & $11.86(8)$ & $16.044(3)$ & $12.42(7)$ & $7.4405(9)$ \\
\hline$c / \AA$ & $6.90(5)$ & $24.922(4)$ & $17.85(11)$ & $37.885(3)$ \\
\hline$A$ & 90 & $93.773(14)$ & 101(4) & 90 \\
\hline$B$ & 90 & $99.581(12)$ & $94(4)(2)$ & $90.297(8)$ \\
\hline$\Gamma$ & 90 & $102.670(12)$ & 99(4) & 90 \\
\hline$U / A^{3}$ & 2799(32) & 3198.3(9) & $1597(37)$ & $6708.1(13)$ \\
\hline$Z$ & 4 & 4 & 2 & 8 \\
\hline$\mu / \mathrm{cm}^{-1}$ & 6.260 & 5.551 & 14.225 & 13.563 \\
\hline Reflections collected & 8618 & 24792 & 11225 & 43287 \\
\hline Independent reflections & 2205 & 11179 & 5524 & 6151 \\
\hline$R_{\text {int }}$ & 0.0782 & 0.0971 & 0.0930 & 0.1898 \\
\hline$R 1$ & 0.0387 & 0.1060 & 0.0799 & 0.0697 \\
\hline$w R 2[I>2 \sigma(I)]$ & 0.0648 & 0.3003 & 0.1613 & 0.1735 \\
\hline
\end{tabular}


Table 4. Details of the X-ray data collections and refinements for 19, 22 and 24

\begin{tabular}{|c|c|c|c|}
\hline Compound & 19 & 22 & 24 \\
\hline Formula & $\mathrm{C}_{31} \mathrm{H}_{28} \mathrm{Cl}_{2} \mathrm{Fe}_{2} \mathrm{~N}_{2} \mathrm{P}_{2} \mathrm{~S}_{7}$ & $\mathrm{C}_{36} \mathrm{H}_{34} \mathrm{Fe}_{2} \mathrm{P}_{2} \mathrm{~S}_{6}$ & $\mathrm{C}_{37} \mathrm{H}_{36} \mathrm{Cl}_{2} \mathrm{Fe}_{2} \mathrm{P}_{2} \mathrm{~S}_{6}$ \\
\hline$M$ & 897.54 & 832.67 & 917.60 \\
\hline Crystal system & Triclinic & Monoclinic & Monoclinic \\
\hline Space group & $P-1$ & $P 2_{1} / n$ & $P 2{ }_{1} / c$ \\
\hline$a / \AA$ & $8.73(5)$ & $7.515(6)$ & $18.848(5)$ \\
\hline$b / \AA$ & $13.73(7)$ & $22.102(13)$ & $12.694(3)$ \\
\hline$c / \AA$ & $15.62(8)$ & $10.965(8)$ & $16.584(5)$ \\
\hline$A$ & $79(3)$ & 90 & 90 \\
\hline$B$ & $75(3)$ & $92.82(2)$ & $95.752(8)$ \\
\hline$\Gamma$ & $78(3)$ & 90 & 90 \\
\hline$U / A^{3}$ & $1750(35)$ & $1819(2)$ & $3947.8(19)$ \\
\hline$Z$ & 2 & 2 & 4 \\
\hline$\mu / \mathrm{cm}^{-1}$ & 15.178 & 12.556 & 12.954 \\
\hline Reflections collected & 12800 & 13577 & 29699 \\
\hline Independent & 6102 & 3191 & 6912 \\
\hline \multicolumn{4}{|l|}{ reflections } \\
\hline$R_{\text {int }}$ & 0.0699 & 0.0988 & 0.1115 \\
\hline$R 1$ & 0.0507 & 0.0934 & 0.0732 \\
\hline$w R 2[I>2 \sigma(I)]$ & 0.1129 & 0.1715 & 0.1378 \\
\hline
\end{tabular}


The X-ray structures of $\mathbf{5}$ and 10, derived from Lawesson's Reagent, consist of the similar frameworks as shown in Figure 1. The structures confirm that the fifteen- and fourteen-membered rings have formed. In the solid state, the structure of $\mathbf{5}$ adopts a more symmetrical structural pattern than $\mathbf{1 0 .}$ In both structures, two swinging $p$-methoxybenzene rings point towards the same side of the cavity being located above the plane defined by the four inward sulfur atoms. However, the structure of 10 assumes a highly puckered fourteen-membered ring conformation. Meanwhile, in both of $\mathbf{5}$ and $\mathbf{1 0}$, the exocyclic sulfur atoms on the two phosphorus centres are cis- to each other; in addition, with all inward atoms $(\mathrm{C}, \mathrm{S}$ and $\mathrm{P})$ of the rings in zigzag position. The angles between the mean plane (defined by four inward sulfur atoms) and the inward phenyl ring(s) are $72.9^{\circ}$ in $\mathbf{5}$, and $24.1[20.9]^{\circ}$ and $23.0[20.3]^{\circ}$ in $\mathbf{1 0}$. Two inward phenyl rings in $\mathbf{1 0}$ are not parallel and the dihedral angle is $46.7[41.1]^{\circ}$. The transannular $\mathrm{P} \cdots \mathrm{P}$ distances of $6.75[6.87] \AA$ in the structure of $\mathbf{1 0}$ fall in the ranges that are observed in related P-S containing macrocycles $[4.97-6.97 \AA] .{ }^{32}$ The transannular $\mathrm{P} \cdots \mathrm{P}$ length of $8.05 \AA$ in $\mathbf{5}$ is significantly longer than that observed in 10, suggesting that the symmetric conformation largely releases the strain of the macrocyclic ring. The geometry around $\mathrm{P}(1)$ and $\mathrm{P}(2)$ is distorted tetrahedral $(\mathrm{S}(3)-\mathrm{P}(1)-\mathrm{S}(1)$ and $\mathrm{S}(1)-\mathrm{P}(1)-\mathrm{S}(2): 113.2(2)^{\circ}$ and $106.7(2)^{\circ}$ in $5,115.56(16)[115.06(16)]^{\circ}$ and $108.84(14)[108.34(16)]^{\circ}$ in 10, being quite similar to those found in the P-Se containing macrocycles. ${ }^{32}$ The P-S single bond lengths in the range of 2.082(4) to $2.110(15) \AA$ and $\mathrm{P}=\mathrm{S}$ double bonds in the range of 1.934(4) to 1.943(11) $\AA$ in the structures of $\mathbf{5}$ and $\mathbf{1 0}$ are typical for the $\mathrm{P}(\mu-\mathrm{S}) \mathrm{S}$ moiety. ${ }^{23,34}$ 
Table 5. Selected bond lengths $(\AA)$ and angles ( $\left(^{\circ}\right)$ (esds in parentheses) for $\mathbf{5}$ and $\mathbf{1 0}$

\begin{tabular}{|c|c|c|}
\hline & Compound $\mathbf{5}$ & Compound $\mathbf{1 0}$ \\
\hline $\mathrm{S}(1)-\mathrm{P}(1)$ & $2.110(15)$ & $2.092(3)[2.097(4)]$ \\
\hline $\mathrm{S}(2)-\mathrm{P}(1)$ & $2.093(9)$ & $2.093(3)[2.082(4)]$ \\
\hline $\mathrm{S}(3)-\mathrm{P}(1)$ & $1.943(11)$ & $1.934(4)[1.941(4)]$ \\
\hline $\mathrm{S}(4)-\mathrm{P}(2)$ & & $2.087(4)[2.078(4)]$ \\
\hline $\mathrm{S}(5)-\mathrm{P}(2)$ & & $2.102(3)[2.100(3)]$ \\
\hline $\mathrm{S}(6)-\mathrm{P}(2)$ & & $1.946(4)[1.950(3)]$ \\
\hline$S(1)-C$ & $1.828(10)$ & $1.829(9)[1.833(9)]$ \\
\hline$S(2)-C$ & $1.819(9)$ & $1.837(12)[1.848(11)]$ \\
\hline$S(4)-C$ & & $1.835(9)[1.851(10)]$ \\
\hline$S(5)-C$ & & $1.867(12)[1.860(11)]$ \\
\hline $\mathrm{S}(1)-\mathrm{P}(1)-\mathrm{S}(2)$ & 106.7(2) & $108.84(14)[108.34(16)]$ \\
\hline $\mathrm{S}(1)-\mathrm{P}(1)-\mathrm{S}(3)$ & $113.2(2)$ & $115.56(16)[115.06(16)]$ \\
\hline $\mathrm{S}(2)-\mathrm{P}(1)-\mathrm{S}(3)$ & 114.6(4) & $106.67(16)[106.83(16)]$ \\
\hline $\mathrm{P}(1)-\mathrm{S}(1)-\mathrm{C}^{*}$ & $104.13(16)$ & $97.7(4)[98.6(3)]$ \\
\hline $\mathrm{P}(1)-\mathrm{S}(2)-\mathrm{C}^{*}$ & $96.4(4)$ & $101.7(3)[102.4(3)]$ \\
\hline $\mathrm{S}(4)-\mathrm{P}(2)-\mathrm{S}(5)$ & & $108.15(14)[107.32(14)]$ \\
\hline $\mathrm{S}(4)-\mathrm{P}(2)-\mathrm{S}(6)$ & & $105.14(17)[107.06(16)]$ \\
\hline $\mathrm{S}(5)-\mathrm{P}(2)-\mathrm{S}(6)$ & & $116.05(16)[115.78(15)]$ \\
\hline $\mathrm{P}(2)-\mathrm{S}(5)-\mathrm{C}^{*}$ & & $99.8(3)[96.9(3)]$ \\
\hline $\mathrm{P}(2)-\mathrm{S}(4)-\mathrm{C}^{*}$ & & $106.2(4)[101.2(4)]$ \\
\hline
\end{tabular}




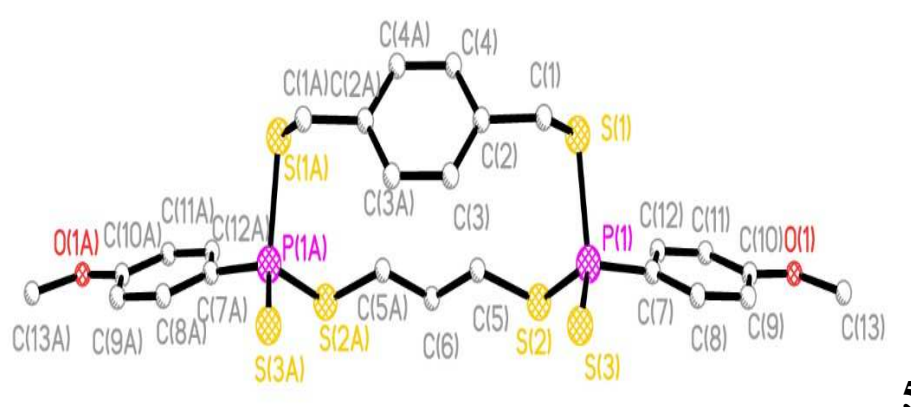

5

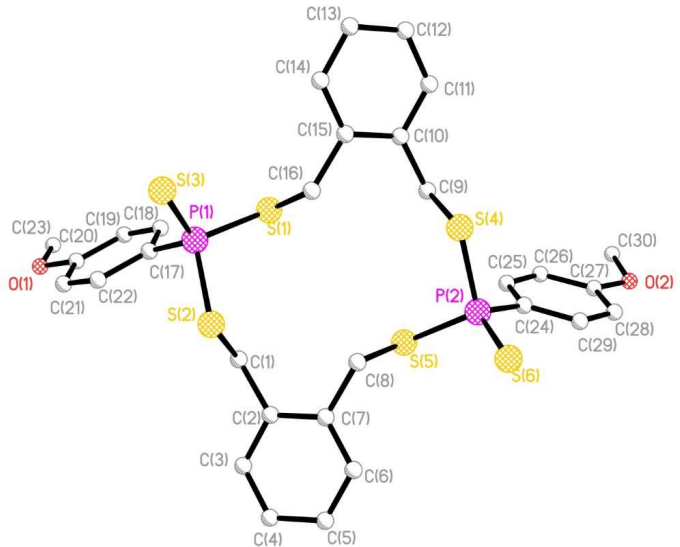

10

Figure 1. Single crystal X-ray structures of compounds $\mathbf{5}$ and $\mathbf{1 0}$

The supramolecular assembly in $\mathbf{5}$ is formed by the intramolecular $\mathrm{C}-\mathrm{H} \cdots \mathrm{S}$ hydrogen bonding $\left[2.680(18) \AA\right.$ with the angle of $\left.125.69^{\circ}\right]$ and intermolecular $\mathrm{C}-\mathrm{H} \cdots \mathrm{S}$ short contacts as shown in Figure 2 . The multi-layered supramolecular assembly in $\mathbf{1 0}$ is supported by the weak intramolecular $\mathrm{C}-\mathrm{H} \cdots \mathrm{S}$ hydrogen bonding and intermolecular $\mathrm{C}-\mathrm{H} \cdots \mathrm{S}$ short contacts and $\pi$-stacking interactions as shown in Figure 3. Interestingly, the intramolecular $\mathrm{C}-\mathrm{H} \cdots \mathrm{S}$ hydrogen bonding are formed by the outward facing $\mathrm{S}$ atoms which acted as hydrogen bond acceptors towards only hydrogens from the methylene groups attached to the phenyl rings rather than alkyl groups, meanwhile, the outward S atoms act also as hydrogen bond acceptors towards the $\mathrm{C}-\mathrm{H}$ groups of a neighboring phenyl rings from another molecule resulting in a multilayered polymeric architecture in $\mathbf{5}$. However, in $\mathbf{1 0}$, the intramolecular $\mathrm{C}-\mathrm{H} \cdots \mathrm{S}$ hydrogen bonds are formed by both the outward $\mathrm{S}$ atoms and inward facing $\mathrm{S}$ atoms which act as hydrogen bond acceptors towards hydrogens from the methylene groups attached to the phenyl rings rather than the hydrogens from aryl rings, meanwhile, both outward $\mathrm{S}$ atoms and the inward $\mathrm{S}$ atoms act as hydrogen bond acceptors towards the $\mathrm{C}-\mathrm{H}$ groups of a neighboring phenyl rings from another molecule giving the multilayered polymeric architecture. 

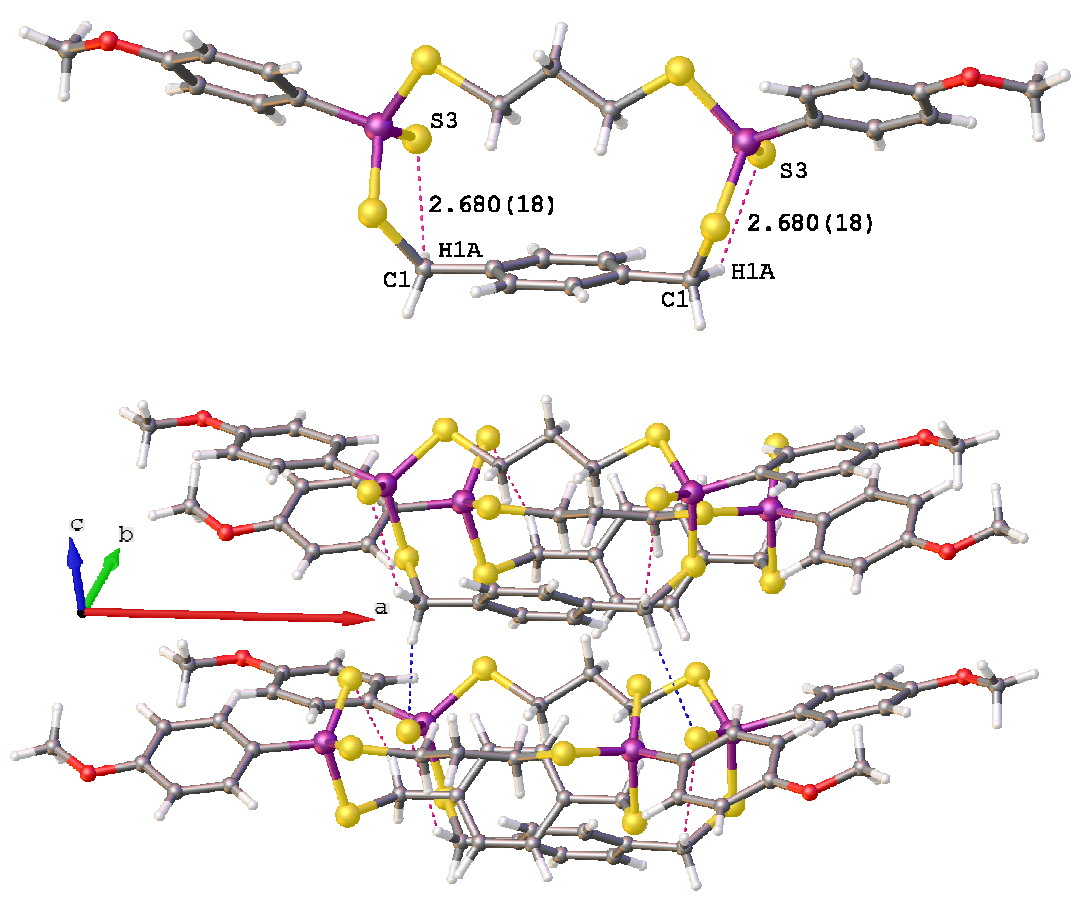

Figure 2. Upper diagram shows the intramolecular $\mathrm{C}(1)-\mathrm{H}(1 \mathrm{~A}) \cdots \mathrm{S}(3)$ hydrogen bond $[2.680(18) \AA$ with the angle of $125.69^{\circ}$ ] in 5; Lower diagram shows the intramolecular C-H $\cdots \mathrm{S}$ hydrogen bonds and intermolecular $\mathrm{C}-\mathrm{H} \cdots \mathrm{S}$ short contacts in supramolecular assembly of 5 .

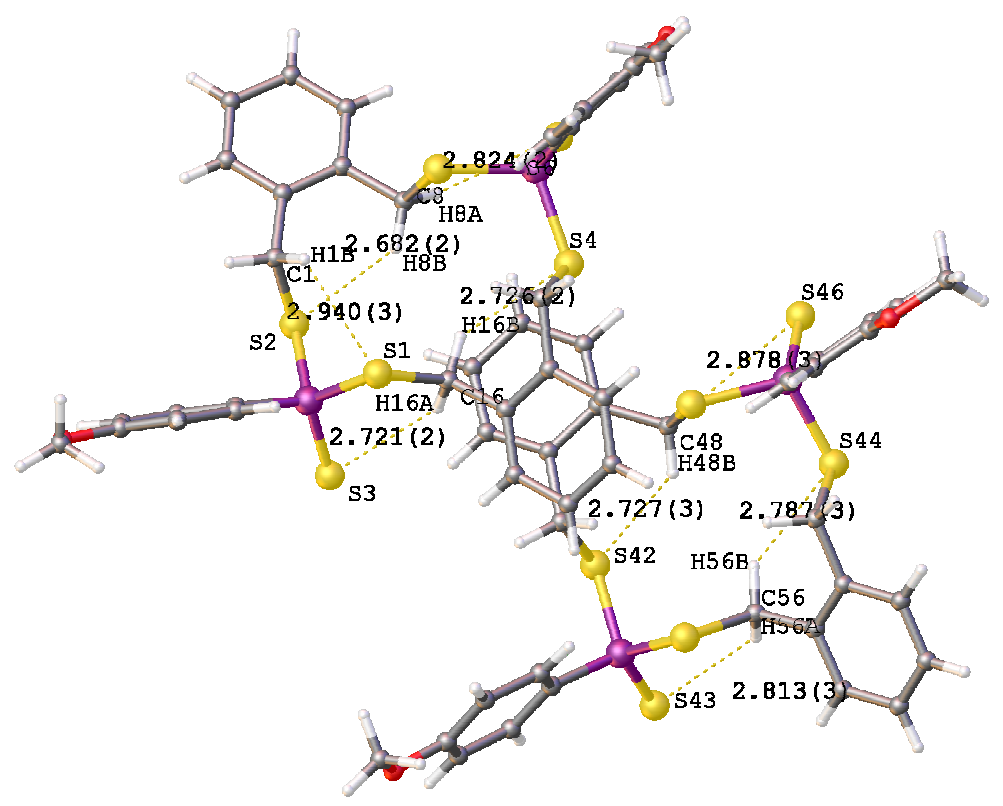




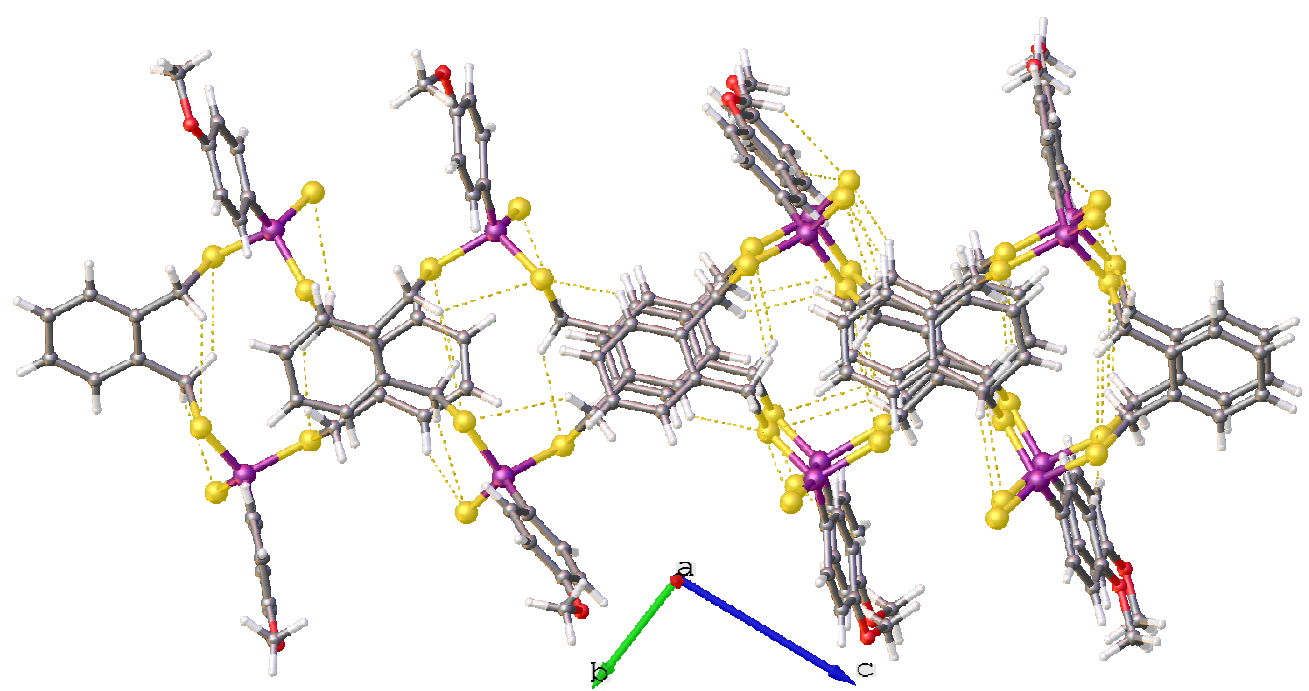

Figure 3. Upper diagram shows the intramolecular hydrogen bonds between outward $\mathrm{S}(2)$ and $\mathrm{H}(8 \mathrm{~B})$ $\left\{2.940(3)[2.727(3)] \AA\right.$ with the $\mathrm{C}(8)-\mathrm{H}(8 \mathrm{~B}) \cdots \mathrm{S}(2)$ angle of $\left.134.26[133.35]^{\circ}\right\}$, between outward $\mathrm{S}(3)$ and $\mathrm{H}(16 \mathrm{~A})$ $\left\{2.721(2)[2.813(3)] \AA\right.$ with the $\mathrm{C}(16)-\mathrm{H}(16 \mathrm{~A}) \cdots \mathrm{S}(3)$ angle of $\left.131.30[127.63]^{\circ}\right] \AA$, between inward $\mathrm{S}(4)$ and $\mathrm{H}(16 \mathrm{~B})\left\{2.726(2)[2.787(3)] \AA\right.$ with the $\mathrm{C}(16)-\mathrm{H}(16 \mathrm{~B}) \cdots \mathrm{S}(4)$ angle of $\left.132.71[133.05]^{\circ}\right\}$ and between inward $\mathrm{S}(6)$ and $\mathrm{H}(8 \mathrm{~A})\left\{2.824(2)[2.878(3)] \AA\right.$ with the $\mathrm{C}(8)-\mathrm{H}(8 \mathrm{~A}) \cdots \mathrm{S}(6)$ angle of $\left.129.20[127.20]^{\circ}\right\}$ in 10; Lower diagram shows the intramolecular $\mathrm{C}-\mathrm{H} \cdots \mathrm{S}$ hydrogen bonds and intermolecular $\mathrm{C}-\mathrm{H} \cdots \mathrm{S}$ short contacts and $\pi$-stacking interactions in supramolecular assembly of $\mathbf{1 0}$.

The structures of compounds 15, 18, 19, 22 and 24, derived from a ferrocene analogue of Lawesson's Reagent, 4-diferrocenyl-1,3,2,4-diathiadiphosphetane 2,4-disulfide (FcLR), have similar frameworks as shown in Figure 4. The structures of 15, 18 and $\mathbf{2 4}$ adopt cradle-like conformations with two ferrocenyl groups lying on the same side and above the cavity, meanwhile, two outward sulfur atoms are located in cis orientations pointing to the opposite side of the two cis ferrocenyl groups and lying below the cavity. However, a boat-like conformation was observed for the structure of $\mathbf{1 8}$ with two ferrocenyl groups and two outward sulfur atoms orientating mutually in trans conformation. Interestingly, the structure of 22 gives a highly symmetric conformation in the solid state, the two outward ferrocenyl rings attached to the phosphorus centers and two inward phenyl rings are almost co-planar with the mean plane of the cavity, though the two outward sulfur atoms lie in trans positions. In 15, the mean plane of four inward sulfur atoms and the inward phenyl ring plane are nearly parallel as measured by a dihedral angle of 
$4.09^{\circ}$. In 18, the dihedral angle between the mean plane of four inward sulfur atoms and the inward phenyl ring is $16.24^{\circ}$. In $\mathbf{1 9}$, the inward thiadiazole plane is nearly perpendicular to the plane of the inward phenyl group, as confirmed by a dihedral angle of $79.06^{\circ}$. Surprisingly, the planes of two inward phenyl rings are perfectly parallel to one another and the planes of two $\mathrm{Cp}$ rings attached to the phosphorus centres are also nearly parallel to one another in $\mathbf{2 2}$, though the new formed macrocyclic ring is highly skewed. The P..P distances of $6.892 \AA$ in 19 and $6.796 \AA$ in 22 fall in the ranges that are observed in related P-Se macrocycles $[4.97-6.97 \AA] .{ }^{32}$ However, the P $\cdots \mathrm{P}$ distances of $7.612 \AA$ in $\mathbf{1 5}$, $8.778 \AA$ in $\mathbf{1 8}$ and $8.363 \AA$ in $\mathbf{2 4}$ are in contrast to that in $\mathbf{1 9}$ and $\mathbf{2 2}$ and significantly longer than that observed in P-Se macrocycles [4.97-6.97 $\AA],{ }^{32}$ indicating the symmetric conformation largely releases the strain of the macrocyclic rings. The geometry around $\mathrm{P}(1)$ and $\mathrm{P}(2)$ is distorted tetrahedral $(\mathrm{S}(3)$ $\mathrm{P}(1)-\mathrm{S}(1)$ and $\mathrm{S}(1)-\mathrm{P}(1)-\mathrm{S}(2): 104(2)^{\circ}$ and $112(2)^{\circ}$ in $15,105.01(10)^{\circ}$ and $108.89(9)^{\circ}$ in $18,116(2)^{\circ}$ and $104.1(12)^{\circ}$ in $\mathbf{1 9}, 115.44(15)^{\circ}$ and $106.19(13)^{\circ}$ in 22 and $115.25(9)^{\circ}$ and $109.53(9)^{\circ}$ in $\mathbf{2 4}$, being quite similar to those found in the P-Se containing macrocycles. ${ }^{32}$ The P-S-C bond angles range from $98(3)^{\circ}$ to $108.6(15)^{\circ}$, reflecting a significant degree of ring-strain in there macrocyclic compounds. The P-S single bond lengths in the range of 2.06(8) to 2.15(4) $\AA$ and $\mathrm{P}=\mathrm{S}$ double bonds in the range of 1.93(7) to $1.96(8) \AA$ in $\mathbf{1 5}, \mathbf{1 8}, \mathbf{1 9}, \mathbf{2 2}$ and $\mathbf{2 4}$ are the typical for the $\mathrm{P}(\mu-\mathrm{S}) \mathrm{S}$ moiety. ${ }^{33,34}$ 
Table 6. Selected bond lengths $(\AA)$ and angles $\left({ }^{\circ}\right)$ (esds in parentheses) for 15, 18, 19, 22 and 24 (dimensions for second independent molecule in square parentheses)

\begin{tabular}{|c|c|c|c|c|c|}
\hline & 15 & 18 & 19 & 22 & 24 \\
\hline $\mathrm{S}(1)-\mathrm{P}(1)$ & $2.08(7)$ & $2.087(2)$ & $2.13(7)$ & $2.096(4)$ & $2.086(2)$ \\
\hline $\mathrm{S}(2)-\mathrm{P}(1)$ & $2.10(9)$ & $2.085(2)$ & $2.12(5)$ & $2.103(4)$ & $2.092(2)$ \\
\hline $\mathrm{S}(3)-\mathrm{P}(1)$ & $1.95(7)$ & $1.947(2)$ & $1.95(3)$ & $1.949(4)$ & $1.947(2)$ \\
\hline $\mathrm{S}(4)-\mathrm{P}(2)$ & $2.08(6)$ & $2.100(2)$ & $2.15(4)$ & & $2.100(2)$ \\
\hline $\mathrm{S}(5)-\mathrm{P}(2)$ & $2.09(8)$ & $2.087(2)$ & $2.06(8)$ & & $2.086(2)$ \\
\hline $\mathrm{S}(6)-\mathrm{P}(2)$ & $1.96(8)$ & $1.940(2)$ & $1.93(7)$ & & $1.938(2)$ \\
\hline $\mathrm{S}(1)-\mathrm{C}^{*}$ & $1.85(5)$ & $1.839(6)$ & $1.75(6)$ & $1.849(9)$ & $1.842(6)$ \\
\hline $\mathrm{S}(2)-\mathrm{C}^{*}$ & $1.83(6)$ & $1.820(6)$ & $1.83(5)$ & $1.847(8)$ & $1.843(6)$ \\
\hline $\mathrm{S}(4)-\mathrm{C}^{*}$ & $1.84(8)$ & $1.842(6)$ & $1.75(6)$ & & $1.829(6)$ \\
\hline $\mathrm{S}(5)-\mathrm{C}^{*}$ & $1.83(3)$ & $1.822(6)$ & $1.84(5)$ & & $1.835(6)$ \\
\hline $\mathrm{S}(1)-\mathrm{P}(1)-\mathrm{S}(2)$ & $112(2)$ & $108.89(9)$ & $104.1(12)$ & $106.19(13)$ & $109.53(9)$ \\
\hline $\mathrm{S}(1)-\mathrm{P}(1)-\mathrm{S}(3)$ & $104(2)$ & $105.01(10)$ & $116(2)$ & $115.44(15)$ & $115.25(9)$ \\
\hline $\mathrm{S}(2)-\mathrm{P}(1)-\mathrm{S}(3)$ & $116(3)$ & $117.53(10)$ & $114(3)$ & $108.14(14)$ & $115.90(9)$ \\
\hline$P(1)-S(1)-C^{*}$ & $106(3)$ & $106.5(2)$ & $98(3)$ & $102.3(3)$ & $104.09(19)$ \\
\hline $\mathrm{P}(1)-\mathrm{S}(2)-\mathrm{C}^{*}$ & 101(4) & $101.0(2)$ & $108(2)$ & $107.3(3)$ & $99.5(3)$ \\
\hline $\mathrm{S}(4)-\mathrm{P}(2)-\mathrm{S}(5)$ & $109(4)$ & 110.61(19) & $106.4(16)$ & & $108.56(10)$ \\
\hline$S(4)-P(2)-S(6)$ & $106(2)$ & $116.12(10)$ & $114(2)$ & & $116.55(11)$ \\
\hline $\mathrm{S}(5)-\mathrm{P}(2)-\mathrm{S}(6)$ & $118(3)$ & $106.46(10)$ & $118(2)$ & & $105.37(12)$ \\
\hline $\mathrm{P}(2)-\mathrm{S}(4)-\mathrm{C}^{*}$ & $105.8(19)$ & $101.3(2)$ & $108.6(15)$ & & $99.5(2)$ \\
\hline$P(2)-S(5)-C^{*}$ & $102(3)$ & $102.9(2)$ & $102.4(18)$ & & $103.5(2)$ \\
\hline
\end{tabular}

$\mathrm{C}^{*}$ might be different numbering in the compound 

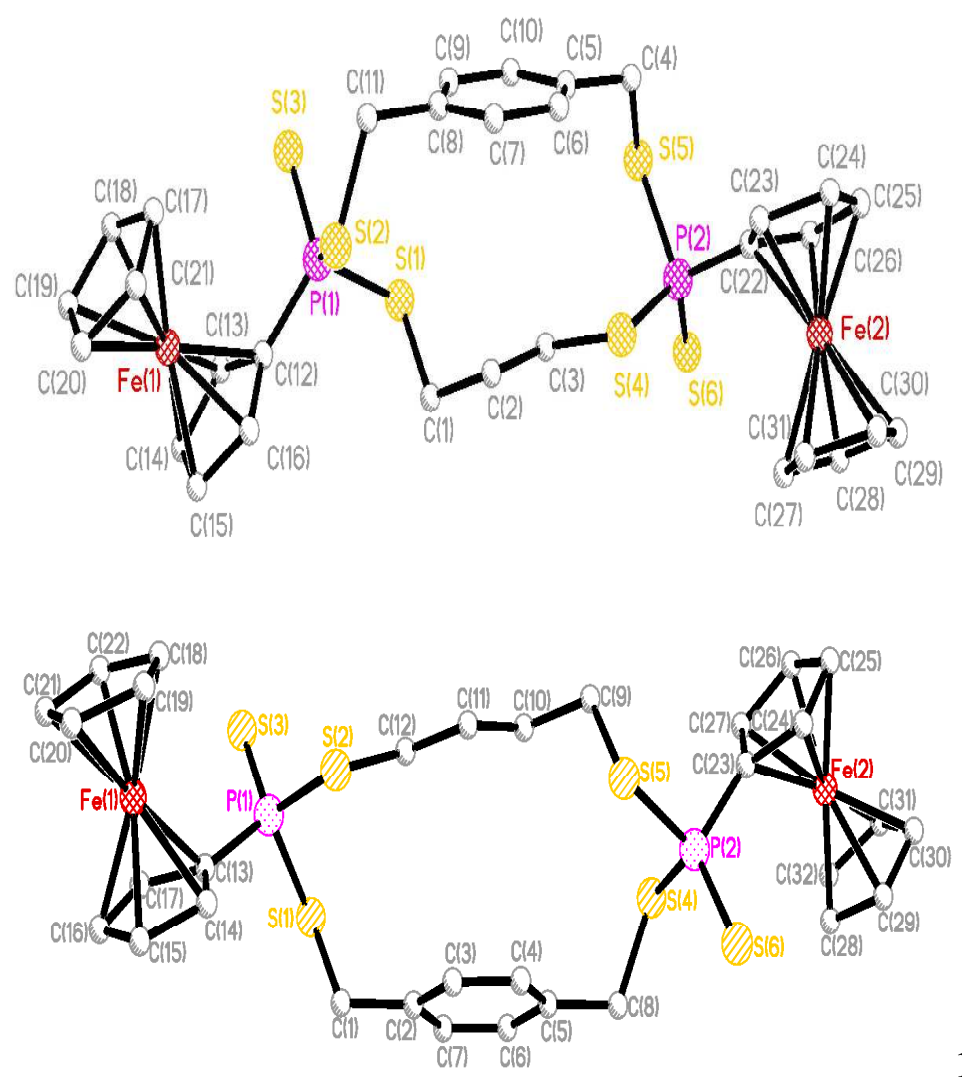

18

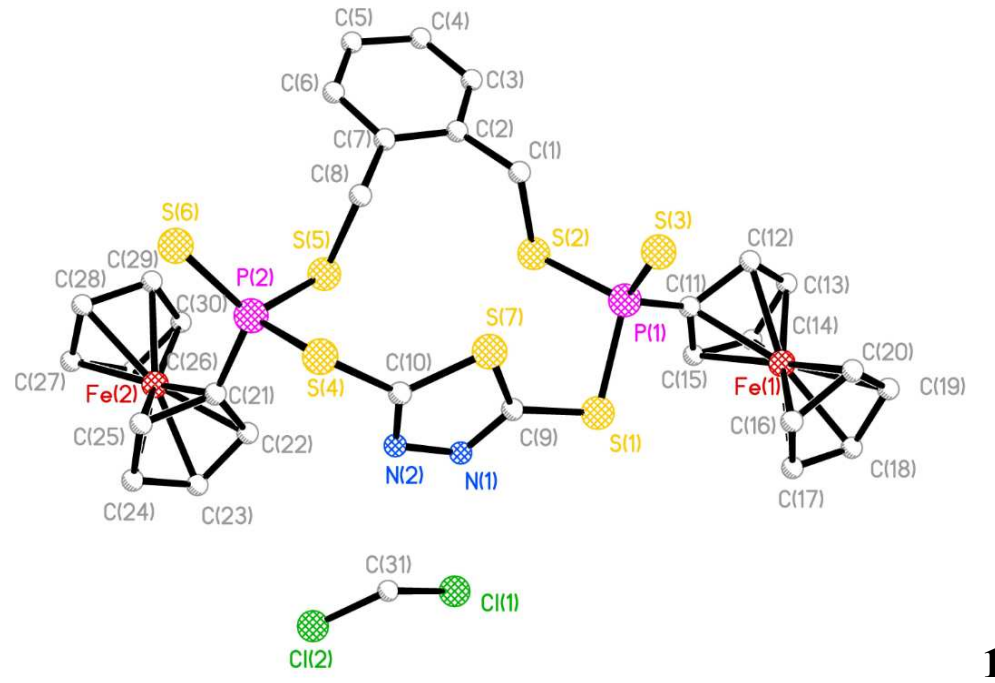



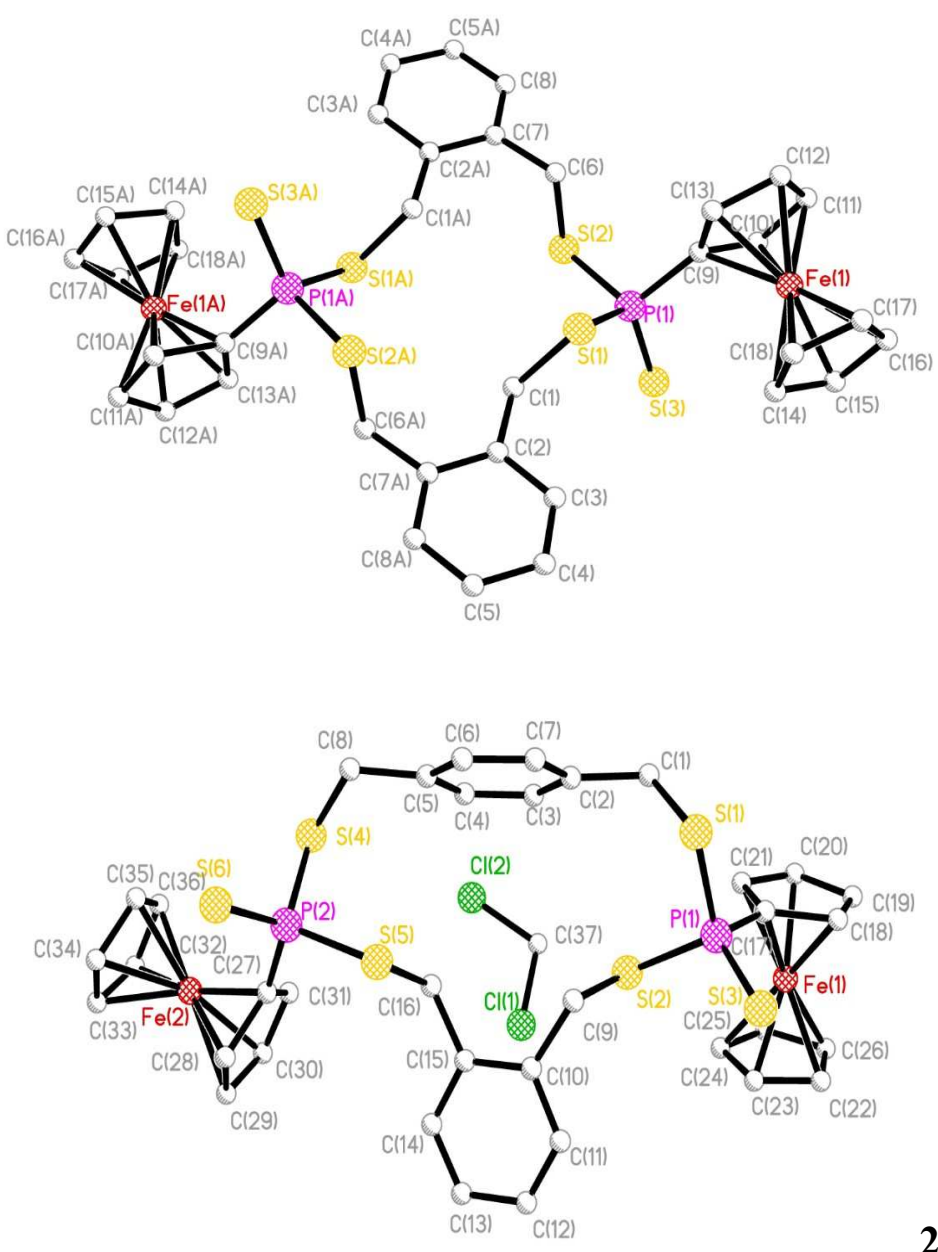

Figure 4. Single crystal X-ray structures of compounds 15, 18, 19, 22 and 24

In the supramolecular structures of $15, \mathbf{1 8}, \mathbf{1 9}, 22$ and 24 , a number of the intramolecular $\mathrm{C}-\mathrm{H} \cdots \mathrm{S}$ hydrogen bonds, intermolecular $\mathrm{C}-\mathrm{H} \cdots \mathrm{S}, \mathrm{C}-\mathrm{H} \cdots \mathrm{O}, \mathrm{C}-\mathrm{H} \cdots \mathrm{N}, \mathrm{C}-\mathrm{H} \cdots \mathrm{Cl}$ and $\mathrm{Cl} \cdots \mathrm{Cl}$ short interactions and $\pi-$ stacking interactions are observed (Figures 5 -9). The structures of $\mathbf{1 5}$ and $\mathbf{1 8}$ have highly similar packing motifs with the intramolecular $\mathrm{C}-\mathrm{H} \cdots \mathrm{S}$ hydrogen bonding, intermolecular $\mathrm{C}-\mathrm{H} \cdots \mathrm{S}$ short contacts and $\pi$-stacking interactions to stabilize the three-dimensional frameworks. Both inward phenyl group and methylene groups in $\mathbf{1 5}$ and $\mathbf{1 8}$ act as different hydrogen-bond donors in the intramolecular hydrogen bonding, where the acceptors are the outward and inward sulfur atoms from the same molecule, in addition, to the intermolecular close contacts, not only the inward phenyl group and 
methylene groups acting as hydrogen-bond donors and the outward and inward sulfur atoms as acceptors, but also the ferrocenyl rings from the neighboring molecules act as hydrogen-bond donors. However, the packing structure of $\mathbf{1 9}$ reveals a different three-dimensional network, compared to the supramolecular frameworks of $\mathbf{1 5}$ and $\mathbf{1 8}$, since intermolecular $\mathrm{C}-\mathrm{H} \cdots \mathrm{Cl}$ short contacts are observed, where the dichloromethane solvent molecules act as double solvent bridges between two layers. ${ }^{35} \mathrm{The} \mathrm{H} \cdots \mathrm{Cl}$ distance $(2.856 \AA)$ is marginally shorter than that reported previously structure $(2.90 \AA) .{ }^{36}$ Additional intermolecular $\mathrm{Cl} \cdots \mathrm{Cl}$ short contacts [3.244 $\AA$, shorter than the van der Waal radii sum (3.6 $\AA$ )] are found between two solvent molecules to stabilize the packing in the lattice. ${ }^{37}$ Though $\mathbf{2 1}$ and $\mathbf{2 4}$ have highly similar gross molecular structures with inward facing phenyl groups, the presence of cocrystalized dichloromethane solvent has a significant effect in supramolecular structure of 24, compared to 22 where all sulfur atoms act as hydrogen-bond acceptors, both methylene groups and phenyl groups act as hydrogen-bond donors. However, in $\mathbf{2 4}$, two outward sulfur atoms act as hydrogen-bond acceptors and only half of the inward sulfur atoms act as hydrogen-bond acceptors. Once again, intermolecular C$\mathrm{H} \cdots \mathrm{Cl}$ short interactions, where the dichloromethane solvent molecules act as double solvent bridges between two layers, are observed to stabilize the three-dimensional framework in $\mathbf{2 4}$, however, no intermolecular $\mathrm{Cl} \cdots \mathrm{Cl}$ short contacts are found. 

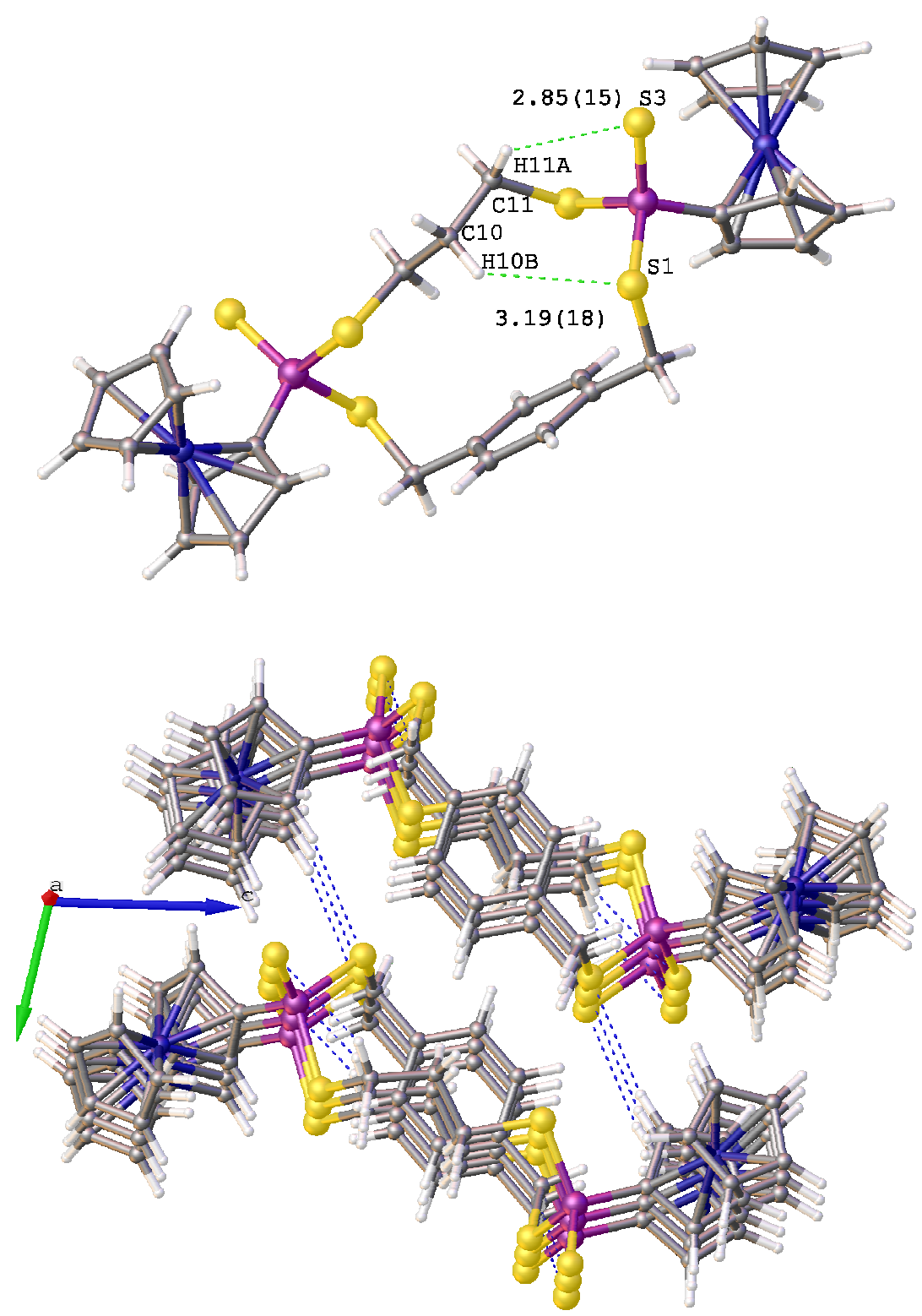

Figure 5. Upper diagram shows the intramolecular $\mathrm{C}(10)-\mathrm{H}(10 \mathrm{~B}) \cdots \mathrm{S}(1)$ and $\mathrm{C}(11)-\mathrm{H}(11 \mathrm{~A}) \cdots \mathrm{S}(3)$ hydrogen bonding [3.19(18) and 2.85(15) $\AA$ with the angles of 137.25 and 129.98 $]$ in 15; Lower diagram shows the intramolecular $\mathrm{C}-\mathrm{H} \cdots \mathrm{S}$ hydrogen bonds and intermolecular $\mathrm{C}-\mathrm{H} \cdots \mathrm{S}$ short contacts and $\pi$-stacking interactions in supramolecular assembly of $\mathbf{1 5}$. 
Figure 6. Upper diagram shows the intramolecular $\mathrm{C}(12)-\mathrm{H}(12 \mathrm{~A}) \cdots \mathrm{S}(1), \mathrm{C}(10)-\mathrm{H}(10 \mathrm{~B}) \cdots \mathrm{S}(1), \mathrm{C}(4)-\mathrm{H}(4) \cdots \mathrm{S}(5)$ and $\mathrm{C}(8)-\mathrm{H}(8 \mathrm{~B}) \cdots \mathrm{S}(6)$ hydrogen bonds [2.8760(15), 3.247(15), 3.18855(15) and 2.7611(17) with the angles of $120.98,128.13,128.13$ and $\left.131.58^{\circ}\right]$ in $\mathbf{1 8}$; Lower diagram shows the intramolecular hydrogen bonding and intermolecular $\mathrm{C}-\mathrm{H} \cdots \mathrm{S}$ short contacts and $\pi$-stacking interactions in supramolecular assembly of $\mathbf{1 8 .}$ 

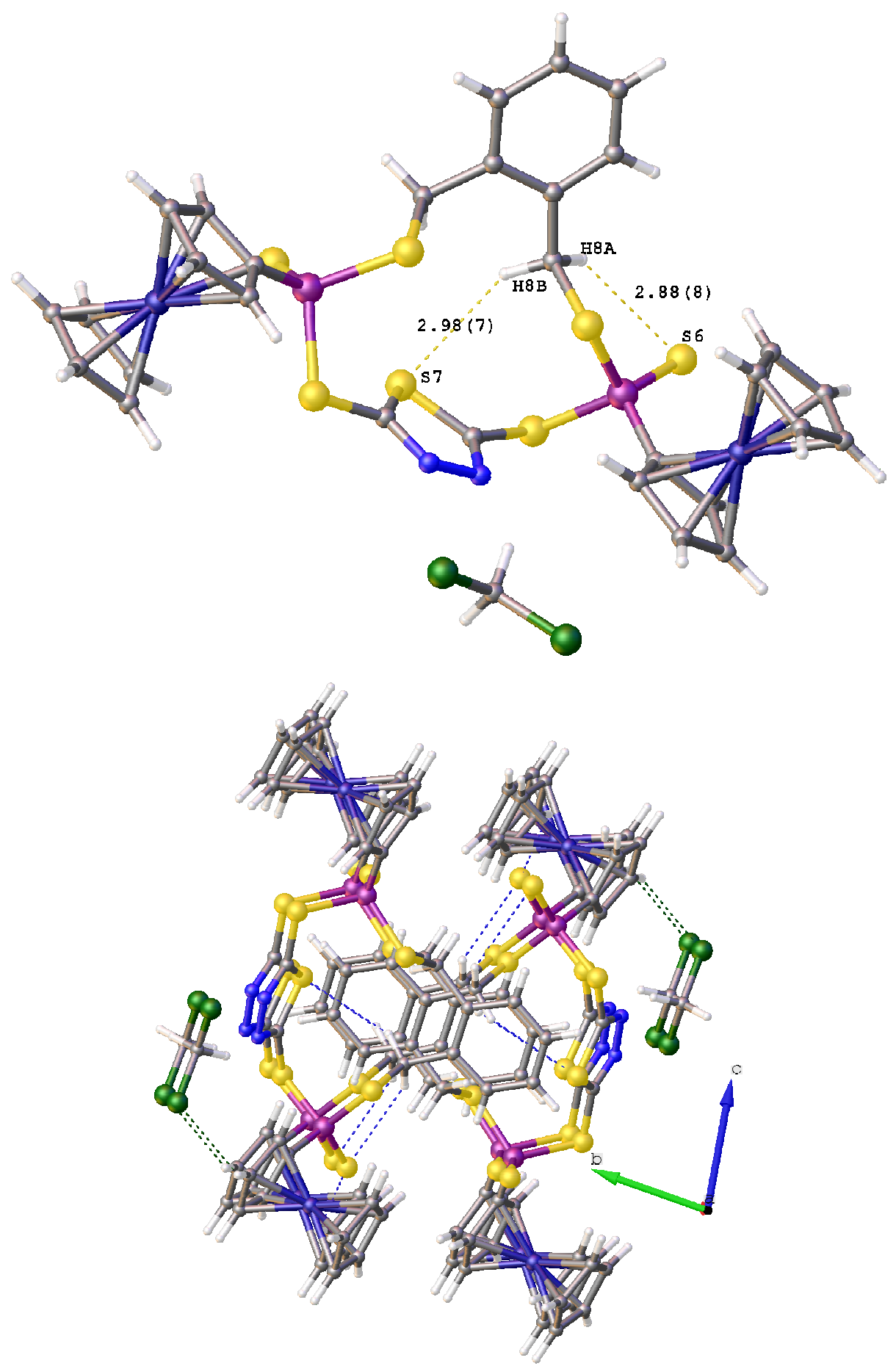

Figure 7. Upper diagram shows the intramolecular $\mathrm{C}(8)-\mathrm{H}(8 \mathrm{~A}) \cdots \mathrm{S}(6)$ and $\mathrm{C}(8)-\mathrm{H}(8 \mathrm{~B}) \cdots \mathrm{S}(7)$ hydrogen bonds [2.88(8) and 2.98(7) $\AA$ with the angle of 126.87 and $142.58^{\circ}$ ] in 19; Lower diagram shows the intramolecular hydrogen bonding, and intermolecular $\mathrm{C}-\mathrm{H} \cdots \mathrm{S}$ and $\mathrm{C}-\mathrm{H} \cdots \mathrm{Cl}$ short contacts and $\pi$-stacking interactions in supramolecular assembly of 19. 

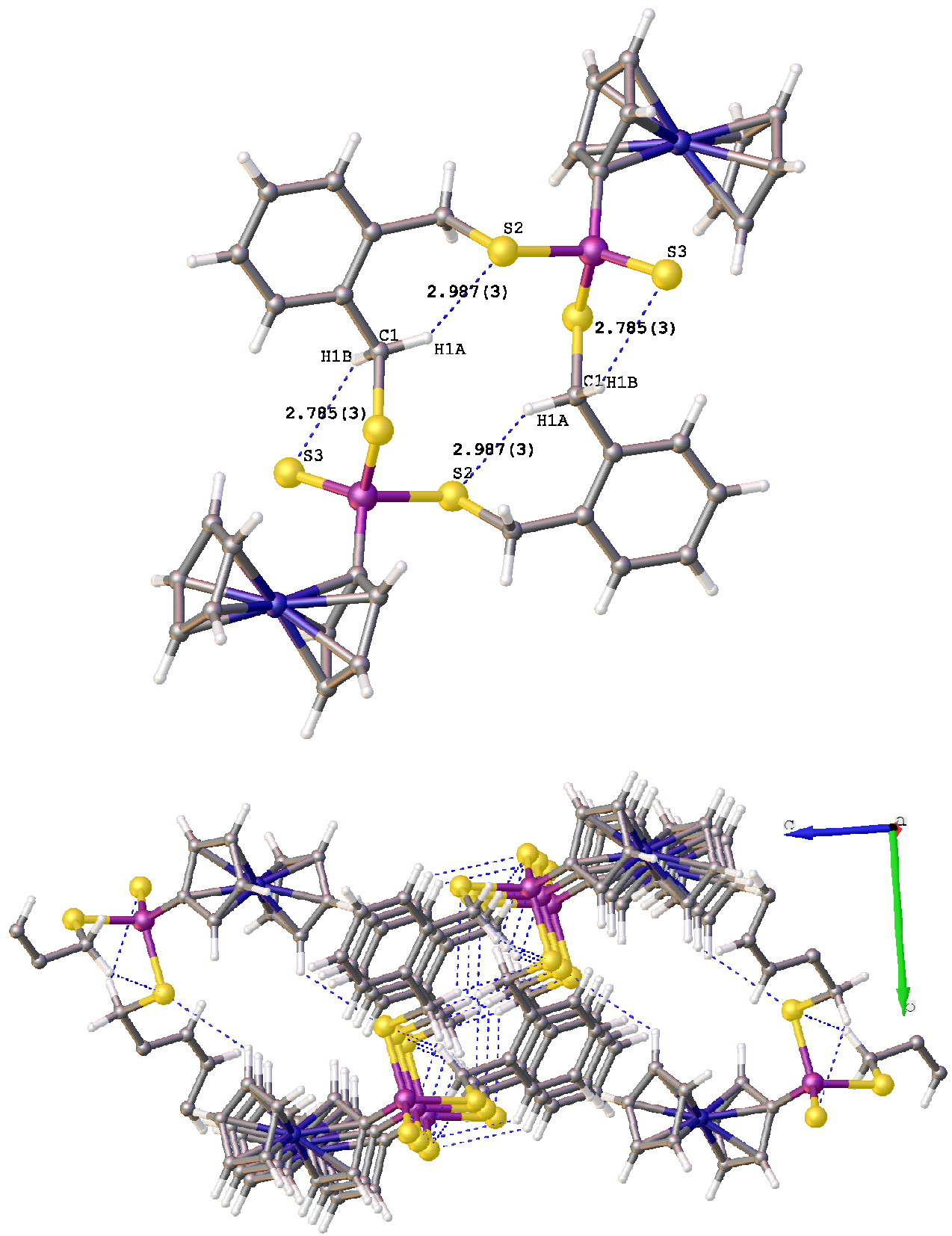

Figure 8. Upper diagram shows the intramolecular $\mathrm{C}(1)-\mathrm{H}(1 \mathrm{~A}) \cdots \mathrm{S}(2)$ and $\mathrm{C}(1)-\mathrm{H}(1 \mathrm{~B}) \cdots \mathrm{S}(3)$ hydrogen bonds [2.987(3) and 2.785(3) $\AA$ with the angles of 122.08 and $129.89^{\circ}$ ] in 22; lower diagram shows the intramolecular hydrogen bonding and intermolecular $\mathrm{C}-\mathrm{H} \cdots \mathrm{S}$ short contacts and $\pi$-stacking interactions in supramolecular assembly of 22. 

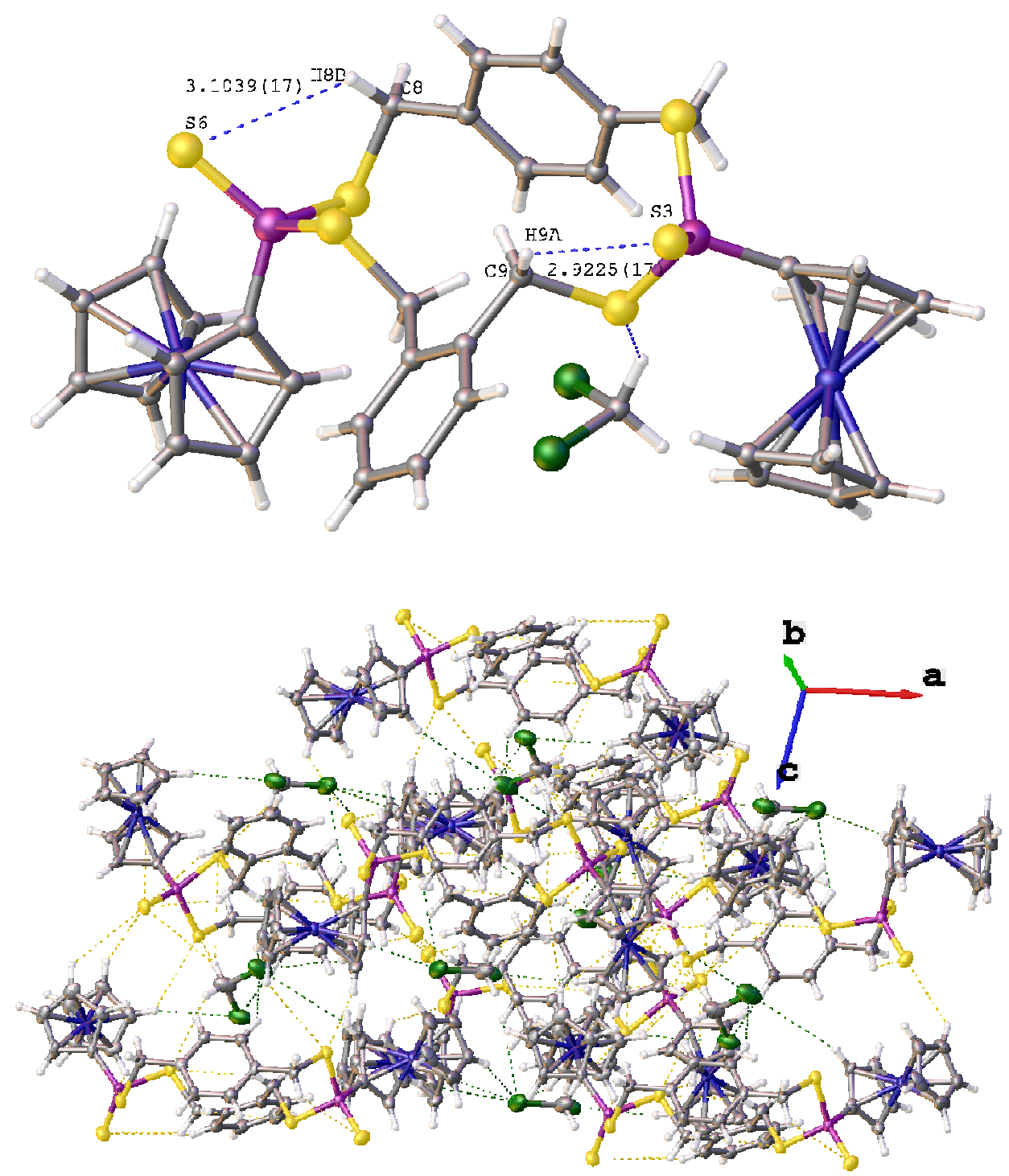

Figure 9. Upper diagram shows the intramolecular $\mathrm{C}(9)-\mathrm{H}(9 \mathrm{~A}) \cdots \mathrm{S}(3)$ and $\mathrm{C}(8)-\mathrm{H}(8 \mathrm{~B}) \cdots \mathrm{S}(6)$ hydrogen bonds [3.1039(17) and 2.9225(17) $\AA$ with the angles of $124.64^{\circ}$ and $124.64^{\circ}$ ] in 24; Lower diagram shows the intramolecular hydrogen bonding, and intermolecular $\mathrm{C}-\mathrm{H} \cdots \mathrm{S}$ and $\mathrm{C}-\mathrm{H} \cdots \mathrm{Cl}$ short contacts in supramolecular assembly of $\mathbf{2 4 .}$

In summary, we have successfully developed a highly efficient route for synthesis of a series of structurally nevel twelve- to sixteen-membered organophosphorus-sulfur macrocycles via an one-pot three-component condensation of four-membered ring thionation reagent, 2,4-bis(4-methoxyphenyl)1,3,2,4-dithiadiphosphetane 2,4-disulfide (LR, Lawesson's Reagent) or 2,4-diferrocenyl-1,3,2,4- 
diathiadiphosphetane 2,4-disulfide (FcLR, a ferrocene analogue of Lawesson's Reagent), alkenyldithiols or aryl-dithiols and dihaloalkanes in the presence of sodium hydride. Seven representative X-ray structures are discussed to confirm the formation of these macrocycles. The resulting data reveal a number of the intramolecular $\mathrm{C}-\mathrm{H} \cdots \mathrm{S}$ hydrogen bonding, intermolecular $\mathrm{C}-\mathrm{H} \cdots \mathrm{S}, \mathrm{C}-\mathrm{H} \cdots \mathrm{Cl}$ and $\mathrm{Cl} \cdots \mathrm{Cl}$ short contacts and $\pi$-stacking interactions observed leading to the multi-layered supramolecular structures. The reported results enhance the application of the multicomponent reaction further, providing an efficient and envirmentally benign route to the preparation of the unusual up to sixteenmembered phosphorus-sulfur macrocycles. The coordination chemistry of these multiple sufur organophosphorus macrocycles will be investigated in due course.

\section{EXPERIMENTAL SECTION}

Unless otherwise stated, all reactions were carried out under on oxygen free nitrogen atmosphere using pre-dried solvents and standard Schlenk techniques, subsequent chromatographic and work up procedures were performed in air. All commercially available reagents including alkyldithiols and aryldithiols were used as supplied without further purification unless stated otherwise. ${ }^{1} \mathrm{H}(400.1 \mathrm{MHz})$, ${ }^{13} \mathrm{C}(100.6 \mathrm{MHz})$ and ${ }^{31} \mathrm{P}-\left\{{ }^{1} \mathrm{H}\right\}(162.0 \mathrm{MHz}) \mathrm{NMR}$ spectra were recorded at $25{ }^{\circ} \mathrm{C}$. IR spectra were recorded as $\mathrm{KBr}$ pellets in the range of $4000-250 \mathrm{~cm}^{-1}$. Mass spectrometry $(\mathrm{m} / \mathrm{z}$, HRMS) data was performed using either atmospheric pressure chemical ionization (APCI) or electron ionization (EI) using a TOM mass analyzer. X-ray crystal data for compounds 5, 10, 15, 18, 19, 22 and 24 were collected using $\omega$ steps accumulating area detector images spanning at least a hemisphere of reciprocal space. All data were corrected for Lorentz polarization effects. Absorption effects were corrected on the basis of multiple equivalent reflections or by semi-empirical methods. Structures were solved by direct methods and refined by full-matrix least-squares against $\mathrm{F}^{2}$ by using the program SHELXTL. ${ }^{38}$ Hydrogen atoms were assigned riding isotropic displacement parameters and constrained to idealized 
geometries. These data can be obtained free of charge via www.ccdc.cam.ac.uk/conts/retrieving.html or from the Cambridge Crystallographic Data centre, 12 Union Road, Cambridge CB2 1EZ, UK; fax (+44) 1223-336-033; e-mail: deposit@ccdc.cam.ac.uk. CCDC Nos 1468813-1468819.

General Procedure for Preparation of Macrocycles 1-10. A suspension of alkyldithiol or aryldithiol (2.0 mmol), sodium hydride $(0.16 \mathrm{~g}, 60 \%$ suspension in oil, $4.0 \mathrm{mmol})$, LR $(0.808 \mathrm{~g}, 2.0$ mmol $)$ and xylylenedibromide $(0.528 \mathrm{~g}, 2.0 \mathrm{mmol})$ in dry THF $(60 \mathrm{~mL})$ was allowed to stir at room temperature for $24 \mathrm{~h}$ giving a yellowish white or off-white suspension. Upon filtering to remove unreacted solid the filtrate was dried in vacuo and the residue was dissolved in dichloromethane $(10 \mathrm{~mL})$, after removing the salt by filtration the liquid solution was concentrated to $c a .2 \mathrm{~mL}$ and was loaded onto a silica gel column (dichloromethane as eluent) to give compounds 1-10.

\section{3,8-Bis(4-methoxyphenyl)-1,5,6,10-tetrahydrobenzo[j] [1,3,6,8] tetrathia[2,7]diphosphacyclododecine}

3,8-disulfide (1). Colorless sticky paste [0.58 g, 45\% based on LR (2.13 mmol)]. Two diastereoisomers were found in $c a .1: 1$ intensity ratio. Selected IR (KBr, $\left.\mathrm{cm}^{-1}\right)$ : 1591(s), 1564(m), 1494(s), 1455(m), 1438(m)，1406(m)，1294(m)，1294(s)，1178(s)，1098(s)，1022(s)，828(s)，799(m)，765(m)，686(vs)， 618(s), 535(s), 500(s), 451(m). ${ }^{1} \mathrm{H}$ NMR $\left(\mathrm{CD}_{2} \mathrm{Cl}_{2}, \delta\right), 8.09-8.00(\mathrm{~m}, 4 \mathrm{H}), 7.86-7.80(\mathrm{~m}, 8 \mathrm{H})$, 7.68-7.60 (m, 8H), 7.57-7.47 (m, 4H), 4.37-4.21 (m, 8H), $4.06(\mathrm{~s}, 6 \mathrm{H}), 3.98(\mathrm{~s}, 6 \mathrm{H}), 3.57-2.62(\mathrm{~m}, 8 \mathrm{H}) \mathrm{ppm} .{ }^{13} \mathrm{C}$ NMR $\left(\mathrm{CD}_{2} \mathrm{Cl}_{2}, \delta\right), 164.1,164.0,135.7,135.6,134.4,133.8,133.6,133.0,132.8,131.0,130.5,129.5$, 115.3, 115.2, 58.5, 58.4, 38.3, 37.9, 35.8, 34.7 ppm. ${ }^{31} \mathrm{P}$ NMR $\left(\mathrm{CD}_{2} \mathrm{Cl}_{2}, \delta\right), 78.9$ and 77.8 ppm. Mass spectrum $\left(\mathrm{EI}^{+}, \mathrm{m} / \mathrm{z}\right), 600[\mathrm{M}]^{+}$. Accurate mass measurement $\left[\mathrm{EI}^{+}, \mathrm{m} / \mathrm{z}\right]: 599.9728[\mathrm{M}]^{+}$, calculated mass for $\mathrm{C}_{24} \mathrm{H}_{26} \mathrm{O}_{2} \mathrm{P}_{2} \mathrm{~S}_{6}: 599.9727$.

4,9-Bis(4-methoxyphenyl)-3,5,8,10-tetrathia-4,9-diphospha-1(1,3)-benzenacycloundecaphane 4,9disulfide (2). White paste [1.17 g, 65\% based on $\mathbf{L R}(3.0 \mathrm{mmol})]$. Two diastereoisomers were found in ca. 3 : 2 intensity ratio. Selected $\mathrm{IR}\left(\mathrm{KBr}, \mathrm{cm}^{-1}\right)$ : 1591(s), 1565(m), 1495(s), 1459(m), 1405(m), 
1293(m), 1257(s), 1178(s), 1098(s), 1023(m), 828(m), 799(m), 687(s), 618(m), 534(s), 502(m). ${ }^{1} \mathrm{H}$ NMR $\left(\mathrm{CD}_{2} \mathrm{Cl}_{2}, \delta\right), 7.90-7.80(\mathrm{~m}, 8 \mathrm{H}), 7.20-6.91(\mathrm{~m}, 16 \mathrm{H}), 4.38-4.28(\mathrm{~m}, 4 \mathrm{H}), 4.16-3.90(\mathrm{~m}, 4 \mathrm{H}), 3.77$ $(\mathrm{s}, 6 \mathrm{H}), 3.76(\mathrm{~s}, 6 \mathrm{H}), 3.11-3.04(\mathrm{~m}, 4 \mathrm{H}), 3.00-2.63(\mathrm{~m}, 4 \mathrm{H}) \mathrm{ppm} .{ }^{13} \mathrm{C} \mathrm{NMR}\left(\mathrm{CD}_{2} \mathrm{Cl}_{2}, \delta\right), 163.2,163.1$, $139.0,138.4,136.9,132.9,132.8,132.4,132.2,131.3,130.8,128.9,128.6,128.4,114.4,114.1,55.6$, 38.6, 37.6, 33.2, 33.1 ppm. ${ }^{31} \mathrm{P}$ NMR $\left(\mathrm{CD}_{2} \mathrm{Cl}_{2}, \delta\right), 81.3$ and $80.9 \mathrm{ppm}$. Mass spectrum $\left(\mathrm{EI}^{+}, \mathrm{m} / \mathrm{z}\right), 600$ $[\mathrm{M}]^{+}$. Accurate mass measurement $\left[\mathrm{EI}^{+}, \mathrm{m} / \mathrm{z}\right]: 599.9723[\mathrm{M}]^{+}$, calculated mass for $\mathrm{C}_{24} \mathrm{H}_{26} \mathrm{O}_{2} \mathrm{P}_{2} \mathrm{~S}_{6}$ : 599.9727.

4,9-Bis(4-methoxyphenyl)-3,5,8,10-tetrathia-4,9-diphospha-1(1,4)-benzenacycloundecaphane 4,9disulfide (3). White solid [0.926 g, 58\% based on LR (2.66 mmol)]. Two diastereoisomers were found in ca. $1: 2$ intensity ratio. Selected IR (KBr, cm $\left.{ }^{-1}\right): 1591(\mathrm{~s}), 1564(\mathrm{~m}), 1495(\mathrm{~s}), 1459(\mathrm{~m}), 1406(\mathrm{~m})$, 1293(m), 1256(s), 1178(s), 1098(s), 1023(s), 828(m), 799(m), 687(s), 618(m), 533(s), 501(m). ${ }^{1} \mathrm{H}$ NMR $\left(\mathrm{CD}_{2} \mathrm{Cl}_{2}, \delta\right), 7.89-7.86(\mathrm{~m}, 8 \mathrm{H}), 7.47-6.93(\mathrm{~m}, 20 \mathrm{H}), 4.44-4.33(\mathrm{~m}, 4 \mathrm{H}), 4.22-4.02(\mathrm{~m}, 4 \mathrm{H}), 3.84(\mathrm{~s}, 6 \mathrm{H})$ $3.82(\mathrm{~s}, 6 \mathrm{H}), 3.72-3.65(\mathrm{~m}, 4 \mathrm{H}), 3.18-2.29(\mathrm{~m}, 4 \mathrm{H}) \mathrm{ppm} .{ }^{13} \mathrm{C} \mathrm{NMR}\left(\mathrm{CD}_{2} \mathrm{Cl}_{2}, \delta\right), 163.2,137.2,135.9$, $133.0,132.8,131.9,131.7,130.7,130.2,129.9,129.5,129.3,128.3,114.3,114.0,55.7,42.8,37.7,34.1$, 25.3 ppm. ${ }^{31} \mathrm{P}$ NMR $\left(\mathrm{CD}_{2} \mathrm{Cl}_{2}, \delta\right), 79.9$ and $79.7 \mathrm{ppm}$. Mass spectrum $\left(\mathrm{EI}^{+}, \mathrm{m} / \mathrm{z}\right), 600[\mathrm{M}]^{+}$. Accurate mass measurement $\left[\mathrm{EI}^{+}, \mathrm{m} / \mathrm{z}\right]: 599.9729[\mathrm{M}]^{+}$, calculated mass for $\mathrm{C}_{24} \mathrm{H}_{26} \mathrm{O}_{2} \mathrm{P}_{2} \mathrm{~S}_{6}: 599.9727$.

3,9-Bis(4-methoxyphenyl)-1,6,7,11-tetrahydro-5H-benzo[k][1,3,7,9]tetrathia[2,8]-

diphosphacyclotridecine 3,9-disulfide (4). Off-white foam [1.313 g, 73\% based on LR (2.45 mmol)]. Two diastereoisomers were found in ca. $1: 3$ intensity ratio. Selected $\mathrm{IR}\left(\mathrm{KBr}, \mathrm{cm}^{-1}\right): 1591(\mathrm{~s}), 1564(\mathrm{~m})$, 1494(s), 1456(m), 1438(m), 1405(m), 1293(m), 1256(s), 1178(s), 1098(s), 1022(s), 828(s), 799(m), 766(m), 687(s), 618(m), 535(s), 501(m). ${ }^{1} \mathrm{H}$ NMR $\left(\mathrm{CD}_{2} \mathrm{Cl}_{2}, \delta\right), 8.10-8.02(\mathrm{~m}, 8 \mathrm{H}), 7.35-7.28(\mathrm{~m}, 8 \mathrm{H})$, 7.12-6.97 (m, 8H), 4.37-4.29 (m, 8H), $3.92(\mathrm{~s}, 6 \mathrm{H}), 3.91(\mathrm{~s}, 6 \mathrm{H}), 3.88-3.03(\mathrm{~m}, 8 \mathrm{H}), 2.52-2.38(\mathrm{~m}, 2 \mathrm{H})$, 2.29-2.08 (m, 2H) ppm. ${ }^{13} \mathrm{C}$ NMR $\left(\mathrm{CD}_{2} \mathrm{Cl}_{2}, \delta\right), 163.3,163.1,134.2,134.1,132.9,132.7,132.3,132.1$, 
$131.6,131.3,128.8,128.7,114.5,114.3,55.6,55.5,37.1,36.2,35.6,33.0,32.7,29.8$ ppm. Mass spectrum $\left(\mathrm{EI}^{+}, \mathrm{m} / \mathrm{z}\right), 614[\mathrm{M}]^{+}$. Accurate mass measurement $\left[\mathrm{EI}^{+}, \mathrm{m} / \mathrm{z}\right]: 613.9884[\mathrm{M}]^{+}$, calculated mass for $\mathrm{C}_{25} \mathrm{H}_{28} \mathrm{O}_{2} \mathrm{P}_{2} \mathrm{~S}_{6}: 613.9883$.

4,10-Bis(4-methoxyphenyl)-3,5,9,11-tetrathia-4,10-diphospha-1(1,4)-benzenacyclododecaphane 4,10disulfide (5). White foam [0.55 g, 45\% based on LR (2.0 mmol)]. Two diastereoisomers were found in ca. $1: 2$ intensity ratio. Selected IR (KBr, cm $\left.{ }^{-1}\right): 1591(\mathrm{~s}), 1564(\mathrm{~m}), 1495(\mathrm{~s}), 1404(\mathrm{~m}), 1293(\mathrm{~s}), 1256(\mathrm{~s})$, 1178(s), 1098(s), 1022(s), 827(s), 799(s), 684(s), 617(s), 535(s), 501(m). ${ }^{1} \mathrm{H}$ NMR $\left(\mathrm{CD}_{2} \mathrm{Cl}_{2}, \delta\right), 7.88-$ $7.81(\mathrm{~m}, 8 \mathrm{H}), 7.39-7.36(\mathrm{~m}, 8 \mathrm{H}), 6.96-6.91(\mathrm{~m}, 8 \mathrm{H}), 4.40-4.25(\mathrm{~m}, 4 \mathrm{H}), 4.11-3.94(\mathrm{~m}, 4 \mathrm{H}), 3.78(\mathrm{~s}, 6 \mathrm{H})$, $3.77(\mathrm{~s}, 6 \mathrm{H}), 2.40-2.25(\mathrm{~m}, 8 \mathrm{H}), 1.78-1.71(\mathrm{~m}, 2 \mathrm{H}), 1.65-1.54(\mathrm{~m}, 2 \mathrm{H}) \mathrm{ppm} .{ }^{13} \mathrm{C} \mathrm{NMR}\left(\mathrm{CD}_{2} \mathrm{Cl}_{2}, \delta\right)$, $163.4,163.3,138.2,138.0,133.1,132.6,132.5,132.4,132.3,130.3,130.0,129.8,128.1,126.9,114.5$ 114.3, 56.0, 38.0, 37.6, 33.1, 32.8, 28.4, 28.0 ppm. ${ }^{31} \mathrm{P}$ NMR $\left(\mathrm{CD}_{2} \mathrm{Cl}_{2}, \delta\right), 80.2$ and 79.7 ppm. Mass spectrum $\left(\mathrm{EI}^{+}, \mathrm{m} / \mathrm{z}\right), 614[\mathrm{M}]^{+}$. Accurate mass measurement $\left[\mathrm{EI}^{+}, \mathrm{m} / \mathrm{z}\right]: 613.9880[\mathrm{M}]^{+}$, calculated mass for $\mathrm{C}_{25} \mathrm{H}_{28} \mathrm{O}_{2} \mathrm{P}_{2} \mathrm{~S}_{6}: 613.9883$.

\section{3,10-Bis(4-methoxyphenyl)-1,5,6,7,8,12-hexahydrobenzo[e] [1,3,8,10]tetrathia[2,9]-}

diphosphacyclotetradecine 3,10-disulfide (6). White foam [0.645 g, 71\% based on LR (1.44 mmol)]. Two diastereoisomers were found in ca. $2: 3$ intensity ratio. Selected IR (KBr, cm $\left.{ }^{-1}\right): 1591(\mathrm{~s}), 1565(\mathrm{~m})$, 1495(s), 1439(m), 1405(m), 1293(m), 1257(s), 1178(s), 1098(s), 1023(m), 828(m), 799(m), 686(s), 618(s), 536(s), 501(m), 446(m). ${ }^{1} \mathrm{H}$ NMR $\left(\mathrm{CD}_{2} \mathrm{Cl}_{2}, \delta\right), 7.92(\mathrm{~d}, J(\mathrm{H}, \mathrm{H})=8.5 \mathrm{~Hz}, 4 \mathrm{H}), 7.89(\mathrm{~d}, J(\mathrm{H}, \mathrm{H})=$ 8.5 Hz, 4H), 7.20-7.10 (m, 8H), 6.96-6.91 (m, 8H), 4.26-4.03 (m, 8H), $3.76(\mathrm{~s}, 6 \mathrm{H}), 3.72(\mathrm{~s}, 6 \mathrm{H}), 3.12-$ $2.87(\mathrm{~m}, 8 \mathrm{H}), 1.73-1.57(\mathrm{~m}, 4 \mathrm{H}), 1.33-1.17(\mathrm{~m}, 4 \mathrm{H}) \mathrm{ppm} .{ }^{13} \mathrm{C} \mathrm{NMR}\left(\mathrm{CD}_{2} \mathrm{Cl}_{2}, \delta\right), 163.6,163.5,135.5$ 134.9, $133.2(\mathrm{~d}, J(\mathrm{P}, \mathrm{C})=13.6 \mathrm{~Hz}), 132.7(\mathrm{~d}, J(\mathrm{P}, \mathrm{C})=13.6 \mathrm{~Hz}), 131.6,131.4,128.6,128.5,127.5,127.3$, 114.9, 114.7, 56.1, 36.4, 36.0, 34.0, 33.4, 28.3, 28.1 ppm. ${ }^{31} \mathrm{P} \mathrm{NMR}\left(\mathrm{CD}_{2} \mathrm{Cl}_{2}, \delta\right), 79.7$ and $79.6 \mathrm{ppm}$. 
Mass spectrum $\left(\mathrm{CI}^{+}, \mathrm{m} / \mathrm{z}\right), 629[\mathrm{M}+\mathrm{H}]^{+}$. Accurate mass measurement $\left[\mathrm{CI}^{+}, \mathrm{m} / \mathrm{z}\right]: 629.0117[\mathrm{M}+\mathrm{H}]^{+}$, calculated mass for $\mathrm{C}_{26} \mathrm{H}_{30} \mathrm{O}_{2} \mathrm{P}_{2} \mathrm{~S}_{6} \mathrm{H}: 629.0118$.

4,11-bBis(4-methoxyphenyl)-3,5,10,12-tetrathia-4,11-diphospha-1(1,3)-benzenacyclotridecaphane 4,11-disulfide (7). White foam [0.655 g, 60\% based on LR (1.75 mmol)]. Two diastereoisomers were found in ca. $1: 2$ intensity ratio. Selected IR (KBr, $\left.\mathrm{cm}^{-1}\right): 1591(\mathrm{~s}), 1565(\mathrm{~m}), 1495(\mathrm{~s}), 1439(\mathrm{~m}), 1405(\mathrm{~m})$, 1293(s), 1265(s), 1177(s), 1098(s), 1023(m), 827(s), 799(s), 685(s), 618(s), 534(s), 501(m). ${ }^{1} \mathrm{H}$ NMR $\left(\mathrm{CD}_{2} \mathrm{Cl}_{2}, \delta\right), 7.92-7.86(\mathrm{~m}, 8 \mathrm{H}), 7.15-6.90(\mathrm{~m}, 16 \mathrm{H}), 4.25-4.14(\mathrm{~m}, 4 \mathrm{H}), 3.96-3.90(\mathrm{~m}, 4 \mathrm{H}), 3.77(\mathrm{~s}, 6 \mathrm{H})$, $3.76(\mathrm{~s}, 6 \mathrm{H}), 3.75-3.72(\mathrm{~m}, 4 \mathrm{H}), 2.96-2.69(\mathrm{~m}, 4 \mathrm{H}), 1.78-1.60(\mathrm{~m}, 8 \mathrm{H}) \mathrm{ppm} .{ }^{13} \mathrm{C} \mathrm{NMR}\left(\mathrm{CD}_{2} \mathrm{Cl}_{2}, \delta\right)$, $163.1,163.0,138.1,137.8,132.9,132.5,130.8,130.4,128.8,128.7,127.6,127.3,126.6,126.4,114.9$, 114.7, 55.6, 38.2, 37.8, 33.4), 33.2, 28.9, 28.6 ppm. ${ }^{31} \mathrm{P} \mathrm{NMR}\left(\mathrm{CD}_{2} \mathrm{Cl}_{2}, \delta\right), 81.3$ and 81.2 ppm. Mass spectrum $\left(\mathrm{CI}^{+}, \mathrm{m} / \mathrm{z}\right), 629[\mathrm{M}+\mathrm{H}]^{+}$. Accurate mass measurement $\left[\mathrm{CI}^{+}, \mathrm{m} / \mathrm{z}\right]: 629.0111[\mathrm{M}+\mathrm{H}]^{+}$, calculated mass for $\mathrm{C}_{26} \mathrm{H}_{30} \mathrm{O}_{2} \mathrm{P}_{2} \mathrm{~S}_{6} \mathrm{H}: 629.0118$.

\section{4,11-Bis(4-methoxyphenyl)-3,5,10,12-tetrathia-4,11-diphospha-1(1,4)-benzenacyclotridecaphane}

4,11-disulfide (8). White foam [0.598 g, 60\% based on LR (1.6 mmol)]. Two diastereoisomers were found in ca. $2: 1$ intensity ratio. Selected IR (KBr, cm $\left.{ }^{-1}\right): 1591(\mathrm{~s}), 1564(\mathrm{~m}), 1494(\mathrm{~s}), 1405(\mathrm{~m}), 1292(\mathrm{~s})$, 1255(s), 1177(s), 1098(s), 1022(s), 826(m), 799(m), 683(s), 617(s), 534(s), 499(m), 447(m). ${ }^{1} \mathrm{H}$ NMR $\left(\mathrm{CD}_{2} \mathrm{Cl}_{2}, \delta\right), 7.88-7.81(\mathrm{~m}, 8 \mathrm{H}), 7.33(\mathrm{~d}, J(\mathrm{H}, \mathrm{H})=5.3 \mathrm{~Hz}, 4 \mathrm{H}), 7.13(\mathrm{~d}, J(\mathrm{H}, \mathrm{H})=5.3 \mathrm{~Hz}, 4 \mathrm{H}), 6.94-6.90$ (m, 8H), 4.36-4.23 (m, 4H), 4.03-3.88 (m, 4H), $3.77(\mathrm{~s}, 6 \mathrm{H}), 3.76(\mathrm{~s}, 6 \mathrm{H}), 2.87-2.32(\mathrm{~m}, 8 \mathrm{H}), 1.65-1.54$ (m, 4H), 1.40-1.28 (m, 4H) ppm. ${ }^{13} \mathrm{C}$ NMR $\left(\mathrm{CD}_{2} \mathrm{Cl}_{2}, \delta\right), 163.1,163.0,137.8,137.7,132.9,132.7,132.3$, 132.2, 129.6, 129.4, 127.7, 126.7, 114.4, 114.2, 55.6, 38.2, 37.8, 33.4, 33.2, 28.9, 28.6 ppm. ${ }^{31} \mathrm{P}$ NMR $\left(\mathrm{CD}_{2} \mathrm{Cl}_{2}, \delta\right), 81.8$ and $81.6 \mathrm{ppm}$. Mass spectrum $\left(\mathrm{CI}^{+}, \mathrm{m} / \mathrm{z}\right), 629[\mathrm{M}+\mathrm{H}]^{+}$. Accurate mass measurement $\left[\mathrm{CI}^{+}, \mathrm{m} / \mathrm{z}\right]: 629.0115[\mathrm{M}+\mathrm{H}]^{+}$, calculated mass for $\mathrm{C}_{26} \mathrm{H}_{30} \mathrm{O}_{2} \mathrm{P}_{2} \mathrm{~S}_{6} \mathrm{H}: 629.0118$. 


\section{3,9-Bis(4-methoxyphenyl)-2,4,8,10-tetrathia-3,9-diphospha-1(2,5)-thiadiazola-6(1,4)-benzena-}

cyclodecaphane 3,9-disulfide (9). Off-white foam [0.719 g, 55\% based on LR (2.0 mmol)]. Two diastereoisomers were found in ca. $2: 1$ intensity ratio. Selected IR (KBr, $\left.\mathrm{cm}^{-1}\right): 1590(\mathrm{vs}), 1564(\mathrm{~m})$, 1495(s), 1459(m), 1407(m), 1295(m), 1258(vs), 1178(s), 1097(vs), 1022(s), 827(s), 800(m), 697(s), 617(m), 527(s), 445(m). ${ }^{1} \mathrm{H}$ NMR $\left(\mathrm{CD}_{2} \mathrm{Cl}_{2}, \delta\right), 7.94-7.73(\mathrm{~m}, 8 \mathrm{H}), 7.28-7.05(\mathrm{~m}, 16 \mathrm{H}), 6.93-6.80(\mathrm{~m}$, 8H), 4.38-3.97 (m, 8H), $3.75(\mathrm{~s}, 6 \mathrm{H}), 3.74(\mathrm{~s}, 6 \mathrm{H}) \mathrm{ppm} .{ }^{13} \mathrm{C}$ NMR $\left(\mathrm{CD}_{2} \mathrm{Cl}_{2}, \delta\right), 163.8,163.7,138.2$, $138.1,135.6,135.4,133.7,133.3,129.9,129.6,124.9,124.0,114.5,114.4,55.7,55.6,37.6,37.5$ ppm. ${ }^{31} \mathrm{P}$ NMR $\left(\mathrm{CD}_{2} \mathrm{Cl}_{2}, \delta\right), 80.0$ and $79.6 \mathrm{ppm}$. Mass spectrum $\left(\mathrm{EI}^{+}, \mathrm{m} / \mathrm{z}\right), 656[\mathrm{M}]^{+}$. Accurate mass measurement [EI $\left.{ }^{+}, \mathrm{m} / \mathrm{z}\right]: 655.9195[\mathrm{M}]^{+}$, calculated mass for $\mathrm{C}_{24} \mathrm{H}_{22} \mathrm{~N}_{2} \mathrm{O}_{2} \mathrm{P}_{2} \mathrm{~S}_{7}: 655.9201$.

7,16-Bis(4-methoxyphenyl)-5,9,14,18-tetrahydrodibenzo[e,l][1,3,8,10]tetrathia[2,9]diphosphacyclotetradecine 7,16-disulfide (10). White foam [0.45 g, 67\% based on LR (1.0 mmol)]. Two diastereoisomers were found in ca. $1: 3$ intensity ratio. Selected IR $\left(\mathrm{KBr}, \mathrm{cm}^{-1}\right): 1591(\mathrm{~s}), 1564(\mathrm{~m})$, 1495(s), 1453(m), 1293(m), 1258(s), 1178(s), 1099(s), 1023(m), 827(m), 800(m), 766(m), 694(s), 618(m), 539(s), 502(m), 442(m). ${ }^{1} \mathrm{H}$ NMR $\left(\mathrm{CD}_{2} \mathrm{Cl}_{2}, \delta\right), 7.96-7.89(\mathrm{~m}, 8 \mathrm{H})$, 7.19-7.08 (m, 16H), 6.98$6.92(\mathrm{~m}, 8 \mathrm{H}), 4.33-4.28(\mathrm{~m}, 8 \mathrm{H}), 4.17-4.11(\mathrm{~m}, 8 \mathrm{H}), 3.75(\mathrm{~s}, 6 \mathrm{H}), 3.74(\mathrm{~s}, 6 \mathrm{H}) \mathrm{ppm} .{ }^{13} \mathrm{C} \mathrm{NMR}\left(\mathrm{CD}_{2} \mathrm{Cl}_{2}\right.$, $\delta), 163.5,163.4,140.2,140.0,134.3,134.2,133.0,132.3,131.5,131.1), 129.0,128.9,114.7,114.5$, 55.7, 55.6, 36.1, 35.7 ppm. ${ }^{31} \mathrm{P}$ NMR $\left(\mathrm{CD}_{2} \mathrm{Cl}_{2}, \delta\right), 77.3$ and $77.1 \mathrm{ppm}$. Mass spectrum $\left(\mathrm{EI}^{+}, \mathrm{m} / \mathrm{z}\right), 676$ $[\mathrm{M}]^{+}$. Accurate mass measurement $\left[\mathrm{EI}^{+}, \mathrm{m} / \mathrm{z}\right]: 676.0042[\mathrm{M}]^{+}$, calculated mass for $\mathrm{C}_{30} \mathrm{H}_{30} \mathrm{O}_{2} \mathrm{P}_{2} \mathrm{~S}_{6}$ : 676.0045 .

General Procedure for Preparation of Macrocycles 11-25. A suspension of alkyldithiol or aryldithiol (2.0 mmol), sodium hydride (0.16 g, 60\% suspension in oil, $4.0 \mathrm{mmol})$, FcLR (0.808 g, 2.0 mmol) and xylylenedibromide $(0.528 \mathrm{~g}, 2.0 \mathrm{mmol})$ in dry THF $(60 \mathrm{~mL})$ was allowed to stir at room temperature for $24 \mathrm{~h}$ giving a reddish yellow or pale yellow suspension. Upon filtering to remove 
unreacted solid the filtrate was dried in vacuo and the residue was dissolved in dichloromethane (10 $\mathrm{mL})$, after removing the salt by filtration the liquid solution was concentrated to ca. $2 \mathrm{~mL}$ and was loaded onto a silica gel column (dichloromethane as eluent) to give compounds 12-25. Another unexpected nine-membered ring 11 was also obtained yellow foam in respective 23\%, 18\%, 24\% and 23\% yields for cases of $13,16,19$ and 22 .

3-Ferrocenyl-1,5-dihydrobenzo[e][1,3,2] dithiaphosphepine 3-sulfide (11). Selected IR ( $\left.\mathrm{KBr}, \mathrm{cm}^{-1}\right)$ : 1491(m), 1440(m), 1409(m), 1253(m), 1216(m), 1203(m), 1160(s), 1020(s), 828(m), 766(s), 671(m), 621(m), 564(s), 545(vs), 483(vs), 450(m). ${ }^{1} \mathrm{H}$ NMR $\left(\mathrm{CD}_{2} \mathrm{Cl}_{2}, \delta\right), 7.25-7.19(\mathrm{~m}, 4 \mathrm{H}), 4.76(\mathrm{~d}, J(\mathrm{P}, \mathrm{H})=$ 14.7 Hz, 1H), $4.72(\mathrm{~d}, J(\mathrm{P}, \mathrm{H})=14.7 \mathrm{~Hz}, 1 \mathrm{H}), 4.50-4.43(\mathrm{~m}, 2 \mathrm{H}), 4.30(\mathrm{~s}, 5 \mathrm{H}), 3.91(\mathrm{~d}, J(\mathrm{P}, \mathrm{H})=14.7 \mathrm{~Hz}$ $2 \mathrm{H}), 3.85(\mathrm{~d}, J(\mathrm{P}, \mathrm{H})=14.7 \mathrm{~Hz}, 2 \mathrm{H}) \mathrm{ppm} .{ }^{13} \mathrm{C} \mathrm{NMR}\left(\mathrm{CD}_{2} \mathrm{Cl}_{2}, \delta\right), 138.6,130.0,128.4,73.7(\mathrm{~d}, J(\mathrm{P}, \mathrm{C})=$ $127 \mathrm{~Hz}), 72.2(\mathrm{~d}, J(\mathrm{P}, \mathrm{C})=12.5 \mathrm{~Hz}), 70.9(\mathrm{~d}, J(\mathrm{P}, \mathrm{C})=15.7 \mathrm{~Hz}), 70.5,31.6(\mathrm{~d}, J(\mathrm{P}, \mathrm{C})=2.6 \mathrm{~Hz}) \mathrm{ppm} .{ }^{31} \mathrm{P}$ $\operatorname{NMR}\left(\mathrm{CD}_{2} \mathrm{Cl}_{2}, \delta\right), 50.2$ ppm. Mass spectrum $\left(\mathrm{EI}^{+}, \mathrm{m} / \mathrm{z}\right), 416[\mathrm{M}]^{+}$. Accurate mass measurement $\left[\mathrm{EI}^{+}\right.$, $\mathrm{m} / \mathrm{z}]: 415.9568[\mathrm{M}]^{+}$, calculated mass for $\mathrm{C}_{18} \mathrm{H}_{17} \mathrm{FePS}_{3}: 415.9574$.

4,9-Diferrocenyl-3,5,8,10-tetrathia-4,9-diphospha-1(1,4)-benzenacycloundecaphane 4,9-disulfide (12). Yellow foam [0.965 g, 64\% based on FcLR (2.1 mmol)]. Two diastereoisomers were found in $c a$. $1: 2$ intensity ratio. Selected IR (KBr, $\left.\mathrm{cm}^{-1}\right): 1510(\mathrm{~m}), 1409(\mathrm{~m}), 1170(\mathrm{~s}), 1105(\mathrm{~m}), 1023(\mathrm{~s}), 1001(\mathrm{~m})$, 823(s), 674(vs), 529(m), 473(vs). ${ }^{1} \mathrm{H}$ NMR $\left(\mathrm{CD}_{2} \mathrm{Cl}_{2}, \delta\right), 7.54-7.30(\mathrm{~m}, 8 \mathrm{H}), 4.65-4.54(\mathrm{~m}, 16 \mathrm{H}), 4.37(\mathrm{~s}$, $10 \mathrm{H}), 4.36(\mathrm{~s}, 10 \mathrm{H}), 4.29-4.02(\mathrm{~m}, 8 \mathrm{H}), 3.30-3.12(\mathrm{~m}, 8 \mathrm{H}) \mathrm{ppm} .{ }^{13} \mathrm{C} \mathrm{NMR}\left(\mathrm{CD}_{2} \mathrm{Cl}_{2}, \delta\right), 137.1,136.2$ 129.8, 129.6, $79.5(\mathrm{~d}, J(\mathrm{P}, \mathrm{C})=105 \mathrm{~Hz}), 79.3(\mathrm{~d}, J(\mathrm{P}, \mathrm{C})=105 \mathrm{~Hz}), 72.3(\mathrm{~d}, J(\mathrm{P}, \mathrm{C})=11.8 \mathrm{~Hz}), 72.2(\mathrm{~d}$, $J(\mathrm{P}, \mathrm{C})=12.0 \mathrm{~Hz}), 71.7(\mathrm{~d}, J(\mathrm{P}, \mathrm{C})=15.0 \mathrm{~Hz}), 71.4(\mathrm{~d}, J(\mathrm{P}, \mathrm{C})=14.9 \mathrm{~Hz}), 71.0,70.9,37.6,37.3,35.2$ 33.9 ppm. ${ }^{31} \mathrm{P}$ NMR $\left(\mathrm{CD}_{2} \mathrm{Cl}_{2}, \delta\right), 81.9$ and $81.8 \mathrm{ppm}$. Mass spectrum $\left(\mathrm{EI}^{+}, \mathrm{m} / \mathrm{z}\right), 756[\mathrm{M}]^{+}$. Accurate mass measurement $\left[\mathrm{EI}^{+}, \mathrm{m} / \mathrm{z}\right]: 755.8847[\mathrm{M}]^{+}$, calculated mass for $\mathrm{C}_{30} \mathrm{H}_{30} \mathrm{Fe}_{2} \mathrm{P}_{2} \mathrm{~S}_{6}: 755.8840$. 


\section{3,9-Diferrocenyl-1,6,7,11-tetrahydro-5H-benzo[k][1,3,7,9] tetrathia[2,8]diphosphacyclotridecine 3,9-} disulfide (13). Yellow foam [1.35 g, 59\% based on FcLR (3.0 mmol)]. Two diastereoisomers were found in ca. $1: 4$ intensity ratio. Selected IR (KBr, $\left.\mathrm{cm}^{-1}\right)$ : 1409(m), 1387(m), 1295(m), 1243(m), 1169(s), 1105(m), 1023(s), 1000(m), 822(s), 767(m), 673(vs), 617(m), 531(s), 476(vs). ${ }^{1} \mathrm{H}$ NMR $\left(\mathrm{CD}_{2} \mathrm{Cl}_{2}, \delta\right), 7.45-7.25(\mathrm{~m}, 8 \mathrm{H}), 4.78-4.75(\mathrm{~m}, 8 \mathrm{H}), 4.67-4.62(\mathrm{~m}, 8 \mathrm{H}), 4.43(\mathrm{~s}, 10 \mathrm{H}), 4.42(\mathrm{~s}, 10 \mathrm{H})$ 4.41-4.36 (m, 4H), 4.19-4.14 (m, 4H), 3.34-3.07 (m, 4H), 2.70-2.60 (m, 4H), 2.16-2.10 (m, 2H), 2.02$1.96(\mathrm{~m}, 2 \mathrm{H}) \mathrm{ppm} .{ }^{13} \mathrm{C} \mathrm{NMR}\left(\mathrm{CD}_{2} \mathrm{Cl}_{2}, \delta\right), 134.4(\mathrm{~d}, J(\mathrm{P}, \mathrm{C})=11.5 \mathrm{~Hz}), 134.3(\mathrm{~d}, J(\mathrm{P}, \mathrm{C})=11.4 \mathrm{~Hz})$, $131.6(\mathrm{~d}, J(\mathrm{P}, \mathrm{C})=6.5 \mathrm{~Hz}), 128.8,128.3,78.6(\mathrm{~d}, J(\mathrm{P}, \mathrm{C})=101 \mathrm{~Hz}), 78.5(\mathrm{~d}, J(\mathrm{P}, \mathrm{C})=101 \mathrm{~Hz}), 72.1(\mathrm{~d}$ $J(\mathrm{P}, \mathrm{C})=12.0 \mathrm{~Hz}), 72.0(\mathrm{~d}, J(\mathrm{P}, \mathrm{C})=11.8 \mathrm{~Hz}), 71.5(\mathrm{~d}, J(\mathrm{P}, \mathrm{C})=15.0 \mathrm{~Hz}), 71.3(\mathrm{~d}, J(\mathrm{P}, \mathrm{C})=14.7 \mathrm{~Hz})$ 70.9, 70.8, 35.6, 35.2, 32.5, 32.1, 29.0, 28.9 ppm. ${ }^{31} \mathrm{P} \mathrm{NMR}\left(\mathrm{CD}_{2} \mathrm{Cl}_{2}, \delta\right), 79.5$ and 79.1 ppm. Mass spectrum $\left(\mathrm{EI}^{+}, \mathrm{m} / \mathrm{z}\right), 770[\mathrm{M}]^{+}$. Accurate mass measurement $\left[\mathrm{EI}^{+}, \mathrm{m} / \mathrm{z}\right]: 769.9004[\mathrm{M}]^{+}$, calculated mass for $\mathrm{C}_{31} \mathrm{H}_{32} \mathrm{Fe}_{2} \mathrm{P}_{2} \mathrm{~S}_{6}: 769.8997$.

\section{4,10-Diferrocenyl-3,5,9,11-tetrathia-4,10-diphospha-1(1,3)-benzenacyclododecaphane 4,10-disulfide}

(14). Yellow foam [1.274 g, 55\% based on FcLR (3.0 mmol)]. Two diastereoisomers were found in $c a$. $2: 1$ intensity ratio. Selected IR (KBr, $\left.\mathrm{cm}^{-1}\right): 1483(\mathrm{~m}), 1408(\mathrm{~m}), 1253(\mathrm{~m}), 1169(\mathrm{~s}), 1105(\mathrm{~m}), 1023(\mathrm{~s})$, 1000(m), 822(s), 705(m), 674(vs), 617(m), 528(s), 475(vs). ${ }^{1} \mathrm{H}$ NMR $\left(\mathrm{CD}_{2} \mathrm{Cl}_{2}, \delta\right), 7.21-7.16(\mathrm{~m}, 8 \mathrm{H})$ 4.59-4.53 (m, 8H), 4.47-4.42 (m, 8H), $4.30(\mathrm{~s}, 10 \mathrm{H}), 4.27(\mathrm{~s}, 10 \mathrm{H}), 4.25-4.19(\mathrm{~m}, 4 \mathrm{H}), 4.08-3.97(\mathrm{~m}$, $4 \mathrm{H}), 2.76-2.65(\mathrm{~m}, 4 \mathrm{H}), 2.55-2.49(\mathrm{~m}, 4 \mathrm{H}), 1.79-1.72(\mathrm{~m}, 4 \mathrm{H}) \mathrm{ppm} .{ }^{13} \mathrm{C} \mathrm{NMR}\left(\mathrm{CD}_{2} \mathrm{Cl}_{2}, \delta\right), 138.6,138.4$, 130.2, 130.1, 129.0, 128.6, 128.4, 128.3, $80.0(\mathrm{~d}, J(\mathrm{P}, \mathrm{C})=102 \mathrm{~Hz}), 79.9(\mathrm{~d}, J(\mathrm{P}, \mathrm{C})=102 \mathrm{~Hz}), 72.1(\mathrm{~d}$, $J(\mathrm{P}, \mathrm{C})=11.8 \mathrm{~Hz}), 72.0(\mathrm{~d}, J(\mathrm{P}, \mathrm{C})=11.8 \mathrm{~Hz}), 71.5(\mathrm{~d}, J(\mathrm{P}, \mathrm{C})=14.5 \mathrm{~Hz}), 71.4(\mathrm{~d}, J(\mathrm{P}, \mathrm{C})=14.6 \mathrm{~Hz})$ 70.9, 70.8, $37.7(\mathrm{~d}, J(\mathrm{P}, \mathrm{C})=19.0 \mathrm{~Hz}), 37.6(\mathrm{~d}, J(\mathrm{P}, \mathrm{C})=19.0 \mathrm{~Hz}), 32.9(\mathrm{~d}, J(\mathrm{P}, \mathrm{C})=42.1 \mathrm{~Hz}), 32.8(\mathrm{~d}$, $J(\mathrm{P}, \mathrm{C})=42.1 \mathrm{~Hz}), 29.4,29.3 \mathrm{ppm} .{ }^{31} \mathrm{P} \mathrm{NMR}\left(\mathrm{CD}_{2} \mathrm{Cl}_{2}, \delta\right), 83.1$ and $83.0 \mathrm{ppm}$. Mass spectrum $\left(\mathrm{EI}^{+}, \mathrm{m} / \mathrm{z}\right)$, 
$770[\mathrm{M}]^{+}$. Accurate mass measurement $\left[\mathrm{EI}^{+}, \mathrm{m} / \mathrm{z}\right]: 769.8998[\mathrm{M}]^{+}$, calculated mass for $\mathrm{C}_{31} \mathrm{H}_{32} \mathrm{Fe}_{2} \mathrm{P}_{2} \mathrm{~S}_{6}$ : 769.8997.

4,10-Diferrocenyl-3,5,9,11-tetrathia-4,10-diphospha-1(1,4)-benzenacyclododecaphane 4,10-disulfide (15). Yellow foam [0.89 g, 58\% based on FcLR (2.0 mmol)]. Two diastereoisomers were found in ca. 9 : 1 intensity ratio. Selected IR $\left(\mathrm{KBr}, \mathrm{cm}^{-1}\right):$ 1409(m), 1387(m), 1363(m), 1300(m), 1236(m), 1300(m), 1236(m), 1174(s), 1102(m), 1024(s), 998(m), 821(s), 672(vs), 618(m), 530(s), 490(s), 472(s). ${ }^{1} \mathrm{H}$ NMR $\left(\mathrm{CD}_{2} \mathrm{Cl}_{2}, \delta\right), 7.36-7.21(\mathrm{~m}, 8 \mathrm{H}), 4.46-4.42(\mathrm{~m}, 16 \mathrm{H}), 4.29(\mathrm{~s}, 10 \mathrm{H}), 4.28(\mathrm{~s}, 10 \mathrm{H}), 4.27-4.21(\mathrm{~m}, 4 \mathrm{H})$ 4.06-3.94 (m, 4H), 2.37-2.16 (m, 8H), 1.74-1.47 (m, 4H) ppm. ${ }^{13} \mathrm{C}$ NMR $\left(\mathrm{CD}_{2} \mathrm{Cl}_{2}, \delta\right), 138.1,137.9$, 129.7, 129.6, $79.9(\mathrm{~d}, J(\mathrm{P}, \mathrm{C})=103 \mathrm{~Hz}), 79.6(\mathrm{~d}, J(\mathrm{P}, \mathrm{C})=103 \mathrm{~Hz}), 72.0(\mathrm{~d}, J(\mathrm{P}, \mathrm{C})=11.6 \mathrm{~Hz}), 71.9(\mathrm{~d}$, $J(\mathrm{P}, \mathrm{C})=11.6 \mathrm{~Hz}), 71.4(\mathrm{~d}, J(\mathrm{P}, \mathrm{C})=14.7 \mathrm{~Hz}), 71.1(\mathrm{~d}, J(\mathrm{P}, \mathrm{C})=14.7 \mathrm{~Hz}), 70.9,70.8,37.5,37.4,32.2$, 31.9, 28.1, 28.0 ppm. ${ }^{31} \mathrm{P}$ NMR $\left(\mathrm{CD}_{2} \mathrm{Cl}_{2}, \delta\right), 81.5$ and $81.2 \mathrm{ppm}$. Mass spectrum $\left(\mathrm{EI}^{+}, \mathrm{m} / \mathrm{z}\right), 770[\mathrm{M}]^{+}$. Accurate mass measurement [EI $\left.I^{+} \mathrm{m} / \mathrm{z}\right]: 765.9087[\mathrm{M}]^{+}$, calculated mass for $\mathrm{C}_{31} \mathrm{H}_{32}{ }^{54} \mathrm{Fe}_{2} \mathrm{P}_{2} \mathrm{~S}_{6}: 765.9090$. 3,10-Diferrocenyl-1,5,6,7,8,12-hexahydrobenzo[e][1,3,8,10]tetrathia[2,9] diphospha-cyclotetradecine 3,10-disulfide (16). Yellow foam [0.53 g, 45\% based on FcLR (2.0 mmol)]. Two diastereoisomers were found in ca. $1: 6$ intensity ratio. Selected IR $\left(\mathrm{KBr}, \mathrm{cm}^{-1}\right): 1409(\mathrm{~m}), 1305(\mathrm{~m}), 1239(\mathrm{~m}), 1170(\mathrm{~s})$, 1105(m), 1024(s), 1002(m), 951(m), 822(s), 765(m), 676(vs), 532(m), 477(vs). ${ }^{1} \mathrm{H}$ NMR $\left(\mathrm{CD}_{2} \mathrm{Cl}_{2}, \delta\right)$, 7.22-7.14 (m, 8H), 4.64-4.60 (m, 8H), 4.50-4.47 (m, 8H), 4.31 (s, 10H), $4.30(\mathrm{~s}, 10 \mathrm{H}), 4.27-4.25(\mathrm{~m}$, 4H), 4.23-4.19 (m, 4H), 4.02-3.96 (m, 4H), 3.04-2.96 (m, 4H), 1.92-1.18 (m, 8H) ppm. ${ }^{13} \mathrm{C}$ NMR $\left(\mathrm{CD}_{2} \mathrm{Cl}_{2}, \delta\right), 135.0,134.9,131.6,131.5,128.9,128.7,79.2(\mathrm{~d}, J(\mathrm{P}, \mathrm{C})=101 \mathrm{~Hz}), 79.1(\mathrm{~d}, J(\mathrm{P}, \mathrm{C})=101$ $\mathrm{Hz}), 72.4(\mathrm{~d}, J(\mathrm{P}, \mathrm{C})=12.1 \mathrm{~Hz}), 72.3(\mathrm{~d}, J(\mathrm{P}, \mathrm{C})=12.1 \mathrm{~Hz}), 71.8(\mathrm{~d}, J(\mathrm{P}, \mathrm{C})=14.7 \mathrm{~Hz}), 71.7(\mathrm{~d}, J(\mathrm{P}, \mathrm{C})=$ 14.7 Hz), 71.3, 71.2, 35.8, 35.6, 32.8, 32.7, 27.7, 27.6 ppm. ${ }^{31} \mathrm{P}$ NMR $\left(\mathrm{CD}_{2} \mathrm{Cl}_{2}, \delta\right), 80.4$ and $80.2 \mathrm{ppm}$. Mass spectrum $\left(\mathrm{EI}^{+}, \mathrm{m} / \mathrm{z}\right), 784[\mathrm{M}]^{+}$. Accurate mass measurement $\left[\mathrm{EI}^{+}, \mathrm{m} / \mathrm{z}\right]: 783.9149[\mathrm{M}]^{+}$, calculated mass for $\mathrm{C}_{32} \mathrm{H}_{34} \mathrm{Fe}_{2} \mathrm{P}_{2} \mathrm{~S}_{6}$ : 783.9153 . 

disulfide (17). Sticky reddish yellow solid $[0.685 \mathrm{~g}, 56 \%$ based on FcLR (1.56 mmol)]. Two diastereoisomers were found in ca. $2: 5$ intensity ratio. Selected IR (KBr, cm $\left.{ }^{-1}\right): 1408(\mathrm{~m}), 1306(\mathrm{~m})$, 1235(m), 1168(s), 1105(m), 1022(s), 10000(m), 820(s), 704(s), 672(vs), 616(m), 528(s), 474(vs). ${ }^{1} \mathrm{H}$ NMR $\left(\mathrm{CD}_{2} \mathrm{Cl}_{2}, \delta\right), 7.49(\mathrm{~s}, 1 \mathrm{H}), 7.44(\mathrm{~s}, 1 \mathrm{H}), 7.30-7.16(\mathrm{~m}, 6 \mathrm{H}), 4.60-4.52(\mathrm{~m}, 8 \mathrm{H}), 4.47-4.42(\mathrm{~m}, 8 \mathrm{H})$, $4.30(\mathrm{~s}, 10 \mathrm{H}), 4.27(\mathrm{~s}, 10 \mathrm{H}), 4.19-4.10(\mathrm{~m}, 4 \mathrm{H}), 4.08-3.98(\mathrm{~m}, 4 \mathrm{H}), 2.81-2.75(\mathrm{~m}, 4 \mathrm{H}), 2.47-2.42(\mathrm{~m}$, 4H), 1.77-1.30 (m, 8H) ppm. ${ }^{13} \mathrm{C}$ NMR $\left(\mathrm{CD}_{2} \mathrm{Cl}_{2}, \delta\right), 138.3,138.2,130.3,130.1,129.0,128.7,128.5$, 128.4, $80.2(\mathrm{~d}, J(\mathrm{P}, \mathrm{C})=101.0 \mathrm{~Hz}), 80.1(\mathrm{~d}, J(\mathrm{P}, \mathrm{C})=101.5 \mathrm{~Hz}), 71.9(\mathrm{~d}, J(\mathrm{P}, \mathrm{C})=12.0 \mathrm{~Hz}), 71.5,71.4$, 71.3, 70.9, 70.8, 38.1, 37.8, 33.0, 32.8, 28.7, 28.4 ppm. ${ }^{31} \mathrm{P}$ NMR $\left(\mathrm{CD}_{2} \mathrm{Cl}_{2}, \delta\right), 82.1$ and 82.0 ppm. Mass spectrum $\left(\mathrm{CI}^{+}, \mathrm{m} / \mathrm{z}\right), 785[\mathrm{M}+\mathrm{H}]^{+}$. Accurate mass measurement $\left[\mathrm{CI}^{+}, \mathrm{m} / \mathrm{z}\right]: 782.9275[\mathrm{M}+\mathrm{H}]^{+}$, calculated mass for $\mathrm{C}_{32} \mathrm{H}_{34}{ }^{54} \mathrm{FeFeP}_{2} \mathrm{~S}_{6} \mathrm{H}: 782.9278$.

4,11-Diferrocenyl-3,5,10,12-tetrathia-4,11-diphospha-1(1,4)-benzenacyclotridecaphane 4,11disulfide (18). Yellow foam [0.666 g, 49\% based on FcLR (1.75 mmol)]. Two diastereoisomers were found in ca. $2: 3$ intensity ratio. Selected IR (KBr, $\left.\mathrm{cm}^{-1}\right): 1510(\mathrm{~m}), 1409(\mathrm{~m}), \mathrm{m} 1238(\mathrm{~m}), 1169(\mathrm{~s})$, 1105(m), 1023(s), 1002(m), 822(s), 673(vs), 529(m), 475(vs). ${ }^{1} \mathrm{H}$ NMR $\left(\mathrm{CD}_{2} \mathrm{Cl}_{2}, \delta\right), 7.33-7.21(\mathrm{~m}, 8 \mathrm{H})$ 4.66-4.52 (m, 8H), 4.48-4.42 (m, 8H), $4.30(\mathrm{~s}, 10 \mathrm{H}), 4.29(\mathrm{~s}, 10 \mathrm{H}), 4.28-4.07(\mathrm{~m}, 4 \mathrm{H}), 3.93-3.56(\mathrm{~m}$, 4H), 2.87-2.76 (m, 4H), 2.47-2.28 (m, 4H), 1.76-1.59 (m, 4H), 1.35-1.18 (m, 4H) ppm. ${ }^{13} \mathrm{C}$ NMR $\left(\mathrm{CD}_{2} \mathrm{Cl}_{2}, \delta\right), 138.0,137.9,129.6,129.3,79.7(\mathrm{~d}, J(\mathrm{P}, \mathrm{C})=102.6 \mathrm{~Hz}), 79.6(\mathrm{~d}, J(\mathrm{P}, \mathrm{C})=102.1 \mathrm{~Hz}), 72.0$ 71.9, 71.6), 71.3, 70.9, 70.8, 37.6, 37.2, 33.0, 32.6, 29.0, 28.5 ppm. ${ }^{31} \mathrm{P}$ NMR $\left(\mathrm{CD}_{2} \mathrm{Cl}_{2}, \delta\right), 82.7$ and 82.6 ppm. Mass spectrum $\left(\mathrm{CI}^{+}, \mathrm{m} / \mathrm{z}\right), 785[\mathrm{M}+\mathrm{H}]^{+}$. Accurate mass measurement $\left[\mathrm{CI}^{+}, \mathrm{m} / \mathrm{z}\right]: 782.9279$ $[\mathrm{M}+\mathrm{H}]^{+}$, calculated mass for $\mathrm{C}_{32} \mathrm{H}_{34}{ }^{54} \mathrm{FeFeP}_{2} \mathrm{~S}_{6} \mathrm{H}: 782.9278$.

3,9-Diferrocenyl-2,4,8,10-tetrathia-3,9-diphospha-1(2,5)-thiadiazola-6(1,2)-benzenacyclodecaphane 3,9-disulfide (19). Dark yellow foam [1.073 g, 66\% based on FcLR (2.0 mmol)]. Two diastereoisomers 
were found in ca. 1: 1 intensity ratio. Selected IR (KBr, cm $\left.{ }^{-1}\right): 1489(\mathrm{~m}), 1450(\mathrm{~m}), 1409(\mathrm{~m}), 1339(\mathrm{~m})$, 1237(m), 1174(s), 1027(s), 951(m), 825(s), 767(m), 689(vs), 534(m), 486(vs), 467(vs). ${ }^{1} \mathrm{H}$ NMR $\left(\mathrm{CD}_{2} \mathrm{Cl}_{2}, \delta\right), 7.27-7.13(\mathrm{~m}, 16 \mathrm{H}), 4.79-4.74(\mathrm{~m}, 8 \mathrm{H}), 4.60-4.58(\mathrm{~m}, 8 \mathrm{H}), 4.38(\mathrm{~s}, 10 \mathrm{H}), 4.37(\mathrm{~s}, 10 \mathrm{H})$ 4.34-4.21 (m, 4H), 4.01-3.97 (m, 4H) ppm. ${ }^{13} \mathrm{C}$ NMR $\left(\mathrm{CD}_{2} \mathrm{Cl}_{2}, \delta\right), 162.5,161.6,134.5,134.2,131.6$, 131.5, 129.5, 129.1, $75.1(\mathrm{~d}, J(\mathrm{P}, \mathrm{C})=89 \mathrm{~Hz}), 74.9(\mathrm{~d}, J(\mathrm{P}, \mathrm{C})=88 \mathrm{~Hz}), 72.7,72.4,71.6,71.4,71.0,70.9$, 38.6, 37.4 ppm. ${ }^{31} \mathrm{P}$ NMR $\left(\mathrm{CD}_{2} \mathrm{Cl}_{2}, \delta\right), 82.3$ and $82.2 \mathrm{ppm}$. Mass spectrum $\left(\mathrm{EI}^{+}, \mathrm{m} / \mathrm{z}\right), 812[\mathrm{M}]^{+}$. Accurate mass measurement $\left[\mathrm{EI}^{+}, \mathrm{m} / \mathrm{z}\right]: 811.8315[\mathrm{M}]^{+}$, calculated mass for $\mathrm{C}_{30} \mathrm{H}_{26} \mathrm{~N}_{2} \mathrm{Fe}_{2} \mathrm{P}_{2} \mathrm{~S}_{7}$ : 811.8313.

3,9-Diferrocenyl-2,4,8,10-tetrathia-3,9-diphospha-1(2,5)-thiadiazola-6(1,3)-benzena-cyclodecaphane 3,9-disulfide (20). Golden foam [0.795 g, 49\% based on FcLR (2.0 mmol)]. Two diastereoisomers were found in ca. $2: 3$ intensity ratio. Selected IR (KBr, $\left.\mathrm{cm}^{-1}\right): 1408(\mathrm{~m}), 1364(\mathrm{~m}), 1317(\mathrm{~m}), 1227(\mathrm{~m})$, 1172(s), 1106(m), 1026(vs), 896(m), 824(s), 686(vs), 532(m), 485(vs), 463(vs). ${ }^{1} \mathrm{H} \mathrm{NMR}\left(\mathrm{CD}_{2} \mathrm{Cl}_{2}, \delta\right)$, $7.42(\mathrm{~s}, 1 \mathrm{H}), 7.41(\mathrm{~s}, 1 \mathrm{H}), 7.24-7.20(\mathrm{~m}, 10 \mathrm{H}), 7.17-7.15(\mathrm{~m}, 4 \mathrm{H}), 4.77-4.69(\mathrm{~m}, 8 \mathrm{H}), 4.61-4.55(\mathrm{~m}, 8 \mathrm{H})$, $4.34(\mathrm{~s}, 10 \mathrm{H}), 4.32(\mathrm{~s}, 10 \mathrm{H}), 4.29-4.03(\mathrm{~m}, 8 \mathrm{H}) \mathrm{ppm} .{ }^{13} \mathrm{C} \mathrm{NMR}\left(\mathrm{CD}_{2} \mathrm{Cl}_{2}, \delta\right), 160.9,160.6,138.2,137.8$, 131.3, 131.0, 128.8, 128.7, 128.2, $128.1,79.9(\mathrm{~d}, J(\mathrm{P}, \mathrm{C})=103 \mathrm{~Hz}), 79.8(\mathrm{~d}, J(\mathrm{P}, \mathrm{C})=104 \mathrm{~Hz}), 72.9(\mathrm{~d}$, $J(\mathrm{P}, \mathrm{C})=12.6 \mathrm{~Hz}), 72.8(\mathrm{~d}, J(\mathrm{P}, \mathrm{C})=12.9 \mathrm{~Hz}), 72.3(\mathrm{~d}, J(\mathrm{P}, \mathrm{C})=12.6 \mathrm{~Hz}), 72.0(\mathrm{~d}, J(\mathrm{P}, \mathrm{C})=13.0 \mathrm{~Hz})$, 71.0, 70.9, 38.6, 38.0 ppm. ${ }^{31} \mathrm{P}$ NMR $\left(\mathrm{CD}_{2} \mathrm{Cl}_{2}, \delta\right), 85.8$ and $83.6 \mathrm{ppm}$. Mass spectrum $\left(\mathrm{EI}^{+}, \mathrm{m} / \mathrm{z}\right), 812$ $[\mathrm{M}]^{+}$. Accurate mass measurement $\left[\mathrm{EI}^{+}, \mathrm{m} / \mathrm{z}\right]: 811.8307[\mathrm{M}]^{+}$, calculated mass for $\mathrm{C}_{30} \mathrm{H}_{26} \mathrm{~N}_{2} \mathrm{Fe}_{2} \mathrm{P}_{2} \mathrm{~S}_{7}$ : 811.8313.

3,9-Diferrocenyl-2,4,8,10-tetrathia-3,9-diphospha-1(2,5)-thiadiazola-6(1,4)-benzen-acyclodecaphane 3,9-disulfide (21). Reddish orange foam $[0.748 \mathrm{~g}, 46 \%$ based on FcLR (2.0 mmol)]. Two diastereoisomers were found in ca. $2: 1$ intensity ratio. Selected IR (KBr, cm $\left.{ }^{-1}\right): 1510(\mathrm{~m}), 1409(\mathrm{~m})$, 1364(m), 1310(m), 1239(m), 171(s), 1105(m), 1024(s), 823(s), 683(vs), 615(m), 533(m), 486(vs), 
459(vs). ${ }^{1} \mathrm{H}$ NMR $\left(\mathrm{CD}_{2} \mathrm{Cl}_{2}, \delta\right), 7.26-7.20$ (m, 16H), 4.76-4.71 (m, 8H), 4.56-4.50 (m, 8H), 4.36 (s, 10H), $4.33(\mathrm{~s}, 10 \mathrm{H}), 4.32-4.22(\mathrm{~m}, 8 \mathrm{H}) \mathrm{ppm} .{ }^{13} \mathrm{C} \mathrm{NMR}\left(\mathrm{CD}_{2} \mathrm{Cl}_{2}, \delta\right), 160.9,160.8,137.7,137.6,130.1,130.0$, 129.9, 129.6, 129.5, 129.4, $78.1(\mathrm{~d}, J(\mathrm{P}, \mathrm{C})=105 \mathrm{~Hz}), 77.9(\mathrm{~d}, J(\mathrm{P}, \mathrm{C})=103 \mathrm{~Hz}), 72.9(\mathrm{~d}, J(\mathrm{P}, \mathrm{C})=12.8$ $\mathrm{Hz}), 72.8(\mathrm{~d}, J(\mathrm{P}, \mathrm{C})=13.0 \mathrm{~Hz}), 72.4(\mathrm{~d}, J(\mathrm{P}, \mathrm{C})=16.0 \mathrm{~Hz}), 72.3(\mathrm{~d}, J(\mathrm{P}, \mathrm{C})=15.1 \mathrm{~Hz}), 71.1,71.0,38.1$, 36.9 ppm. ${ }^{31} \mathrm{P}$ NMR $\left(\mathrm{CD}_{2} \mathrm{Cl}_{2}, \delta\right), 83.3$ and 82.8 ppm. Mass spectrum $\left(\mathrm{EI}^{+}, \mathrm{m} / \mathrm{z}\right), 812[\mathrm{M}]^{+}$. Accurate mass measurement $\left[\mathrm{EI}^{+}, \mathrm{m} / \mathrm{z}\right]: 811.8313[\mathrm{M}]^{+}$, calculated mass for $\mathrm{C}_{30} \mathrm{H}_{26} \mathrm{~N}_{2} \mathrm{Fe}_{2} \mathrm{P}_{2} \mathrm{~S}_{7}: 811.8313$.

\section{7,16-diferrocenyl-5,9,14,18-tetrahydrodibenzo[e,l][1,3,8,10]tetrathia[2,9]-}

diphosphacyclotetradecine 7,16-disulfide (22). Yellow solid [0.492 g, 59\% based on FcLR (1.0 mmol)]. Two diastereoisomers were found in ca. $2: 1$ intensity ratio. Selected IR (KBr, cm $\left.{ }^{-1}\right): 1490(\mathrm{~m})$, 1452(m), 1173(s), 1106(m), 1025(s), 1002(m), 821(s), 767(s), 696(s), 672(vs), 533(s), 478(vs). ${ }^{1} \mathrm{H}$ NMR $\left(\mathrm{CD}_{2} \mathrm{Cl}_{2}, \delta\right), 7.26-7.19(\mathrm{~m}, 16 \mathrm{H}), 4.68-4.67(\mathrm{~m}, 8 \mathrm{H}), 4.53-4.51(\mathrm{~m}, 8 \mathrm{H}), 4.31(\mathrm{~s}, 10 \mathrm{H}), 4.30(\mathrm{~s}, 10 \mathrm{H})$ 4.28-4.23 (m, 8H), 4.10-4.06 (m, 8H) ppm. ${ }^{13} \mathrm{C}$ NMR $\left(\mathrm{CD}_{2} \mathrm{Cl}_{2}, \delta\right), 134.5,134.4,131.5,131.4,128.9$, 128.8, 77.6 (d, $J(\mathrm{P}, \mathrm{C})=99 \mathrm{~Hz}), 77.5(\mathrm{~d}, J(\mathrm{P}, \mathrm{C})=101 \mathrm{~Hz}), 72.3(\mathrm{~d}, J(\mathrm{P}, \mathrm{C})=12.0 \mathrm{~Hz}), 72.1(\mathrm{~d}, J(\mathrm{P}, \mathrm{C})=$ $11.9 \mathrm{~Hz}), 71.4(\mathrm{~d}, J(\mathrm{P}, \mathrm{C})=15.0 \mathrm{~Hz}), 71.3(\mathrm{~d}, J(\mathrm{P}, \mathrm{C})=14.9 \mathrm{~Hz}), 71.0,70.8,35.3,35.2 \mathrm{ppm} .{ }^{31} \mathrm{P}$ NMR $\left(\mathrm{CD}_{2} \mathrm{Cl}_{2}, \delta\right), 78.2$ and 78.0 ppm. Mass spectrum $\left(\mathrm{EI}^{+}, \mathrm{m} / \mathrm{z}\right), 832[\mathrm{M}]^{+}$. Accurate mass measurement $\left[\mathrm{EI}^{+}\right.$ $\mathrm{m} / \mathrm{z}]: 831.9157[\mathrm{M}]^{+}$, calculated mass for $\mathrm{C}_{36} \mathrm{H}_{34} \mathrm{Fe}_{2} \mathrm{P}_{2} \mathrm{~S}_{6}: 831.9159$.

4,10-Diferrocenyl-3,5,9,11-tetrathia-4,10-diphospha-1(1,2),7(1,3)-dibenzenacyclododecaphane 4,10disulfide (23). Yellow foam [0.535 g, 64\% based on FcLR (1.0 mmol)]. Two diastereoisomers were found in ca. $8: 1$ intensity ratio. Selected $\mathrm{IR}\left(\mathrm{KBr}, \mathrm{cm}^{-1}\right): 1485(\mathrm{~m}), 1444(\mathrm{~m}), 1408(\mathrm{~m}), 1305(\mathrm{~m})$, 1168(s), 1105(m), 1022(s), 821(s), 762(m), 668(vs), 616(m), 526(s), 472(vs). ${ }^{1} \mathrm{H}$ NMR $\left(\mathrm{CD}_{2} \mathrm{Cl}_{2}, \delta\right), 7.60$ $(\mathrm{s}, 1 \mathrm{H}), 7.57(\mathrm{~s}, 1 \mathrm{H}), 7.27-7.06(\mathrm{~m}, 14 \mathrm{H}), 4.65-4.56(\mathrm{~m}, 8 \mathrm{H}), 4.48-4.44(\mathrm{~m}, 8 \mathrm{H}), 4.29(\mathrm{~s}, 10 \mathrm{H}), 4.28(\mathrm{~s}$ $10 \mathrm{H}), 4.14-4.05(\mathrm{~m}, 8 \mathrm{H}), 3.89-3.37(\mathrm{~m}, 8 \mathrm{H}) \mathrm{ppm} .{ }^{13} \mathrm{C} \mathrm{NMR}\left(\mathrm{CD}_{2} \mathrm{Cl}_{2}, \delta\right), 139.0,138.9,138.8,138.3$, $135.3,130.9,130.7,130.1,129.8,128.7,128.6,128.4,128.3,79.0(\mathrm{~d}, J(\mathrm{P}, \mathrm{C})=101 \mathrm{~Hz}), 78.7(\mathrm{~d}, J(\mathrm{P}, \mathrm{C})$ 
$=103 \mathrm{~Hz}), 72.4(\mathrm{~d}, J(\mathrm{P}, \mathrm{C})=11.8 \mathrm{~Hz}), 72.3(\mathrm{~d}, J(\mathrm{P}, \mathrm{C})=11.4 \mathrm{~Hz}), 71.7(\mathrm{~d}, J(\mathrm{P}, \mathrm{C})=15.0 \mathrm{~Hz}), 71.6(\mathrm{~d}$, $J(\mathrm{P}, \mathrm{C})=14.9 \mathrm{~Hz}), 71.1,71.0,37.6,37.2,35.1,34.8 \mathrm{ppm} .{ }^{31} \mathrm{P}$ NMR $\left(\mathrm{CD}_{2} \mathrm{Cl}_{2}, \delta\right), 81.6$ and $80.2 \mathrm{ppm}$. Mass spectrum $\left(\mathrm{EI}^{+}, \mathrm{m} / \mathrm{z}\right), 832[\mathrm{M}]^{+}$. Accurate mass measurement $\left[\mathrm{EI}^{+}, \mathrm{m} / \mathrm{z}\right]: 831.9155[\mathrm{M}]^{+}$, calculated mass for $\mathrm{C}_{36} \mathrm{H}_{34} \mathrm{Fe}_{2} \mathrm{P}_{2} \mathrm{~S}_{6}: 831.9159$.

4,10-Diferrocenyl-3,5,9,11-tetrathia-4,10-diphospha-1(1,2),7(1,4)-dibenzenacyclododecaphane 4,10disulfide (24). Orange foam [0.468 g, 56\% based on FcLR (1.0 mmol)]. Two diastereoisomers were found in $c a .3: 1$ intensity ratio. Selected IR (KBr, $\left.\mathrm{cm}^{-1}\right): 1409(\mathrm{~m}), 1239(\mathrm{~m}), 1170(\mathrm{~s}), 111(\mathrm{~m}), 1024(\mathrm{~s})$, 823(s), 772(m), 736(m), 674(vs), 529(m), 476(vs). ${ }^{1} \mathrm{H}$ NMR $\left(\mathrm{CD}_{2} \mathrm{Cl}_{2}, \delta\right), 7.22-7.12$ (m, 8H), 7.03-6.98 (m, 8H), 4.67-4.62 (m, 8H), 4.54-4.49 (m, 8H), $4.30(\mathrm{~s}, 10 \mathrm{H}), 4.29(\mathrm{~s}, 10 \mathrm{H}), 4.07-3.93(\mathrm{~m}, 4 \mathrm{H}), 3.77-$ $3.70(\mathrm{~m}, 4 \mathrm{H}), 3.63-3.57(\mathrm{~m}, 4 \mathrm{H}), 3.26-3.10(\mathrm{~m}, 4 \mathrm{H}) \mathrm{ppm} .{ }^{13} \mathrm{C} \mathrm{NMR}\left(\mathrm{CD}_{2} \mathrm{Cl}_{2}, \delta\right), 137.6,137.3,135.1$, 135.0, 131.2, 130.7, 129.8, 129.3, 128.2, 127.8, $78.6(\mathrm{~d}, J(\mathrm{P}, \mathrm{C})=103 \mathrm{~Hz}), 78.5(\mathrm{~d}, J(\mathrm{P}, \mathrm{C})=102 \mathrm{~Hz})$ $72.3(\mathrm{~d}, J(\mathrm{P}, \mathrm{C})=11.9 \mathrm{~Hz}), 72.2(\mathrm{~d}, J(\mathrm{P}, \mathrm{C})=12.0 \mathrm{~Hz}), 71.6(\mathrm{~d}, J(\mathrm{P}, \mathrm{C})=15.0 \mathrm{~Hz}), 71.5(\mathrm{~d}, J(\mathrm{P}, \mathrm{C})=15.0$ $\mathrm{Hz}), 71.0,70.9,37.6,37.2,36.2,35.1$ ppm. ${ }^{31} \mathrm{P} \mathrm{NMR}\left(\mathrm{CD}_{2} \mathrm{Cl}_{2}, \delta\right), 81.9$ and $81.7 \mathrm{ppm}$. Mass spectrum $\left(\mathrm{EI}^{+}, \mathrm{m} / \mathrm{z}\right), 832[\mathrm{M}]^{+}$. Accurate mass measurement $\left[\mathrm{EI}^{+}, \mathrm{m} / \mathrm{z}\right]: 831.9156[\mathrm{M}]^{+}$, calculated mass for $\mathrm{C}_{36} \mathrm{H}_{34} \mathrm{Fe}_{2} \mathrm{P}_{2} \mathrm{~S}_{6}: 831.9159$.

2,9-Diferrocenyl-1,3,8,10-tetrathia-2,9-diphosphacyclooctadecane 2,9-disulfide (25). Reddish yellow paste $[0.630 \mathrm{~g}, 46 \%$ based on FcLR $(1.75 \mathrm{mmol})]$. Selected IR $\left(\mathrm{KBr}, \mathrm{cm}^{-1}\right): 1433(\mathrm{~m}), 1409(\mathrm{~m})$, 1247(m), 1171(s), 1106(m), 1024(s), 1000(m), 824(s), 678(vs), 533(m), 480(s). ${ }^{1} \mathrm{H}$ NMR $\left(\mathrm{CD}_{2} \mathrm{Cl}_{2}, \delta\right)$, 4.55-4.53 (m, 4H), 4.44-4.42 (m, 4H), $4.28(\mathrm{~s}, 10 \mathrm{H}), 3.34(\mathrm{t}, J(\mathrm{H}, \mathrm{H})=6.8 \mathrm{~Hz}, 4 \mathrm{H}), 2.94-2.72(\mathrm{~m}, 8 \mathrm{H})$, 2.49-2.41 (m, 4H), 1.81-1.54 (m, 4H), 1.35-1.22 (m, 4H) ppm. ${ }^{13} \mathrm{C}$ NMR $\left(\mathrm{CD}_{2} \mathrm{Cl}_{2}, \delta\right), 81.1(\mathrm{~d}, J(\mathrm{P}, \mathrm{C})=$ 101.4 Hz), $72.1(\mathrm{~d}, J(\mathrm{P}, \mathrm{C})=11.7 \mathrm{~Hz}), 71.7(\mathrm{~d}, J(\mathrm{P}, \mathrm{C})=14.9 \mathrm{~Hz}), 71.1,34.6,33.2,34.6,30.3,29.5,28.4$, 24.4 ppm. ${ }^{31} \mathrm{P}$ NMR $\left(\mathrm{CD}_{2} \mathrm{Cl}_{2}, \delta\right), 81.6 \mathrm{ppm}$. Mass spectrum $\left(\mathrm{EI}^{+}, \mathrm{m} / \mathrm{z}\right), 792[\mathrm{M}]^{+}$. Accurate mass measurement $\left[\mathrm{EI}^{+}, \mathrm{m} / \mathrm{z}\right]: 791.9777[\mathrm{M}]^{+}$, calculated mass for $\mathrm{C}_{32} \mathrm{H}_{42} \mathrm{Fe}_{2} \mathrm{P}_{2} \mathrm{~S}_{6}: 791.9779$. 


\section{ASSOCIATED CONTENT}

\section{Supporting Information}

The Supporting Information is available free of charge on the ACS Publications website at DOI:

Copies of ${ }^{1} \mathrm{H}$ and ${ }^{13} \mathrm{C}$ NMR spectra of compounds 1-25 and ORTEP Plots of X-ray structures of compounds 5, 10, 15, 18, 19, 22 and 24.

\section{AUTHOR INFORMATION}

\section{Corresponding Author}

*E-mail: jdw3@st-andrews.ac.uk

\section{Notes}

The authors declare no competing financial interest.

\section{ACKNOWLEDGEMENTS}

We are grateful to the University of St Andrews for financial support and the EPSRC National Mass Spectrometry Service Centre (Swansea) for mass spectral measurements.

\section{REFERENCES}

(1) Stoken, H. N. J. Am. Chem. 1897, 19, 782-796.

(2) Evans, D. A.; Andrews, G. C. Acc. Chem. Res. 1974, 7, 147-155.

(3) Vedejs, E. Acc. Chem. Res. 1984, 17, 358-364.

(4) Sato, R.; Ohyama, T.; Ogawa, S. Heterocycles 1995, 41, 893-896.

(5) Toste, F. D.; Still, I. W. J. J. Am. Chem. Soc. 1995, 117, 7261-7262.

(6) Searle, P. A.; Molinski, T. F. J. Org. Chem. 1994, 59, 6600-6605. 
(7) Davidson, B. S.; Ford, P. W.; Wahlman, M. Tetrahedron Lett. 1994, 35, 7185-7188.

(8) Behar, M.; Danishefsky, S. J. J. Am. Chem. Soc. 1993, 115, 7017-7018.

(9) Ford, P. W.; Davidson, B. S. J. Org. Chem. 1993, 58, 4522-4523.

(10) Davidson, B. S.; Molinski, T. F.; Barrows, L. R.; Ireland, C. M. J. Am. Chem. Soc. 1991, 113, 4709-4710.

(11) Caminade, A. M.; Majoral, J. P. Chem. Rev. 1994, 94, 1183-1213.

(12) Mullen, G. E. D.; Blower, P. J.; Price, D. J.; Powell, A. K.; Howard, M. J.; Went, M. J. Inorg. Chem. 2000, 39, 4093-4098.

(13) Edwards, P. G.; Newman, P. D.; Malik, K. M. A. Angew. Chem. Int. Ed. 2000, 39, 2922-2924.

(14) Blower, P. J.; Jeffery, J. C.; MacLean, E.; Pinkrah, V. T.; Sowrey, F. E.; Teat, S. J.; Went, M. J. Inorg. Chim. Acta 2004, 357, 4129-4138.

(15) Janosik, T.; Bergman, J.; Stensland, B.; Stälhandske, C.; J. Chem. Soc. Perkin Trans. 1 2002, 330-334.

(16) Macho, S.; Rees, C. W.; Rodriguez, T.; Torroba, T. Chem. Commun. 2001, 403-404.

(17) Bergman, J.; Stälhandske, C. Tetrahedron Lett. 1994, 35, 5279-5282.

(18) Ogawa, S.; Ohmiya, T.; Kikuchi, T.; Kawaguchi, A.; Saito, S.; Sai, A.; Kawai, Y.; Niizuma, S.; Nakajo, S.; Kimura, T.; Sato, R. J. Organomet. Chem. 2000, 661, 136-145.

(19) Ogawa, S.; Sugawara, M.; Kawai, Y.; Niizuma, S.; Kimura, T.; Sato, R. Tetrahedron Lett. 1999, 40, 9101-9106.

(20) Ogawa, S.; Nobuta, S.; Nakayama, R.; Kawai, Y.; Niizuma, S.; Sato, R. Chem. Lett. 1996, 757758.

(21) Ogawa, S.; Saito, S.; Kikuchi, T.; Kawai, Y.; Niizuma, S.; Sato, R. Chem. Lett. 1995, 321-322.

(22) Ogawa, S.; Yamashita, M.; Sato, R. Tetrahedron Lett. 1995, 36, 587-590. 
(23) Ogawa, S.; Yomoji, N.; Chida, S.; Sato, R. Chem. Lett. 1994, 507-510.

(24) Jesberger, M.; Davis, T. P.; Barner, L. Synthesis 2003, 1929-1958.

(25) Ozturk, T.; Ertas, E.; Mert, O. Chem. Rev. 2007, 107, 5210-5278.

(26) Foreman, M. R. St. J.; Slawin, A. M. Z.; Woollins, J. D. J. Chem. Soc. Dalton Trans. 1996, 3653-3657.

(27) Parveen, S.; Kilian, P.; Slawin, A. M. Z.; Woollins, J. D. Dalton Trans. 2006, 2586-2590.

(28) Michael, P.C.; Levinson, M. I. Tetrahedron 1985, 41, 5061-5087.

(29) Lecher, H. Z.; Greenwood, R. A.; Whitehouse, K. C. Chao, T. H. J. Am. Chem. Soc. 1956, 78, 5018-5022.

(30) Charles, H. G. Phosphorus Sulfur Silicon Relat. Elem. 1987, 31, 77-80.

(31) Shabana, R. Phosphorus Sulfur Silicon Relat. Elem. 1987, 29, 293-296.

(32) Hua, G.; Slawin, A. M. Z.; Randall, R. A. M.; Corde, D. B.; Crawford, L.; Bühl, M.; Woollins, J. D. Chem. Commun. 2013, 49, 2619-2621.

(33) Hua, G.; Randall, R. A. M.; Slawin, A. M. Z.; Woollins, J. D. Tetrahedron 2013, 69, 5299-5305.

(34) Hua, G.; Du, J.; Cordes, D. B.; Arachchige, K.S. A.; Slawin, A. M. Z.; Woollins, J. D. Phosphorus Sulfur Silicon Relat. Elem. 2016, 191, 341-346.

(35) Cheng, Y.; Chen, L. S.; Liu, Q. K.; Wu, J.; Guo, D. S. Acta Cryst. 2011, C67, o244-248.

(36) Erben, M.; Růžička, A.; Vinklárek, J.; Štáva, V.; Veselẏ, D. Acta Cryst. 2007, E63, m3067.

(37) Hathwar, V. R.; SRoopan, . M.; Subashini, R.; Khan, F. N.; Row, T. N. G. J. Chem. Sci. 2010, $122,677-685$.

(38) Sheldrick, G. M. Acta Cryst. 2008, A64, 112-122. 